Supplementary materials for 'Outside of the palace walls: Generative linguists in the 1970s and 1980s', by Frederick J. Newmeyer.

Language 96(3).e173-e199, 2020.

Outside of the palace walls: Web-based supplemental material

FREDERICK J. NEWMEYER

University of Washington, University of British Columbia, and Simon Fraser University 


\section{National Science Foundation}

\section{Division of Social Sciences}

Grants in support of linguistics research awarded during fiscal years 1966 through 1972

(see the following pages) 


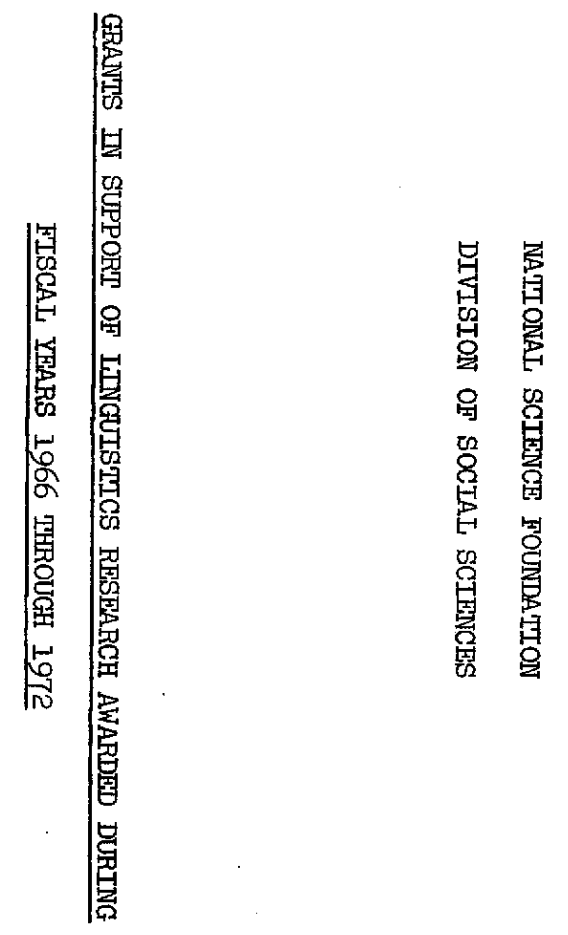




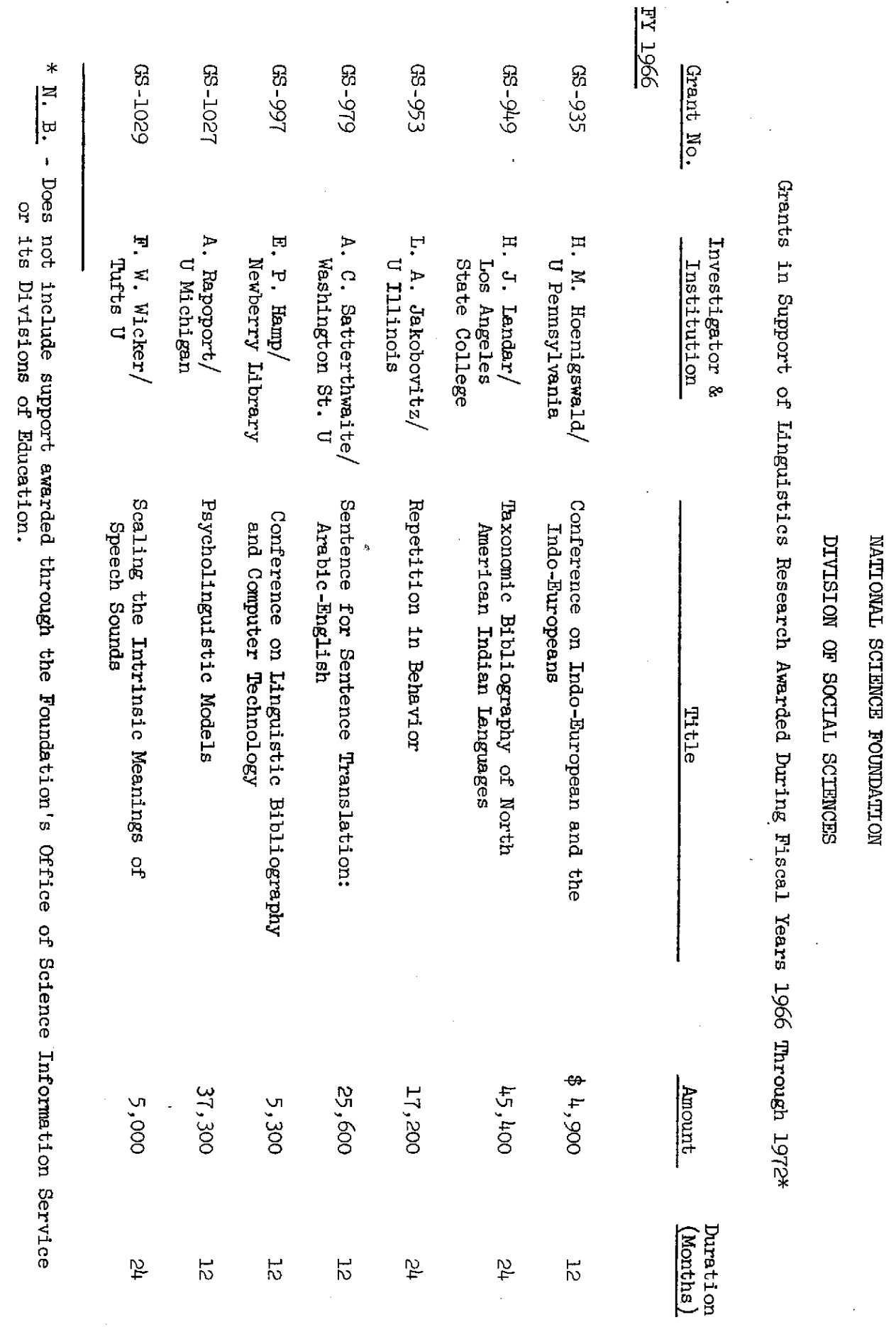




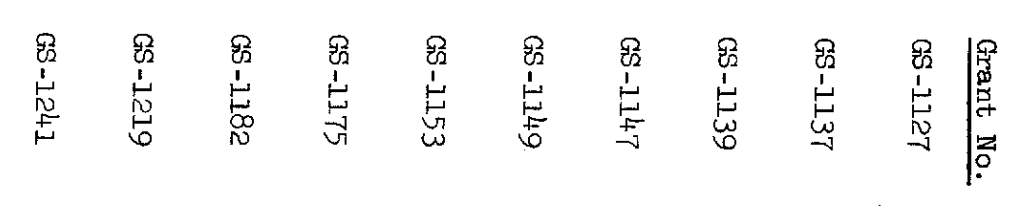

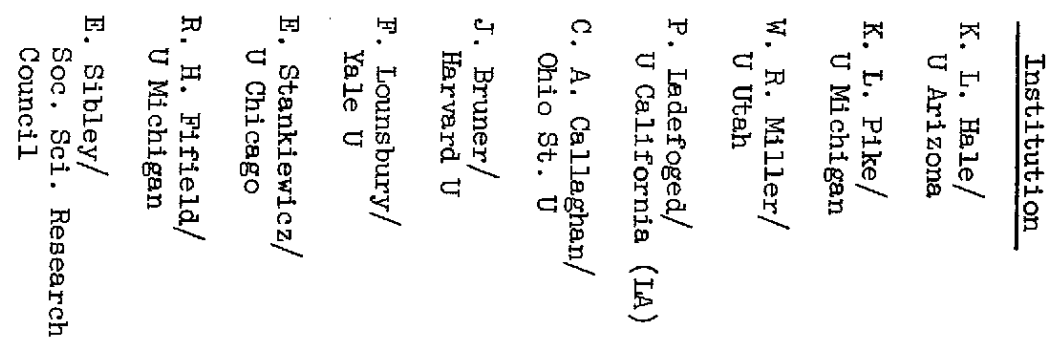

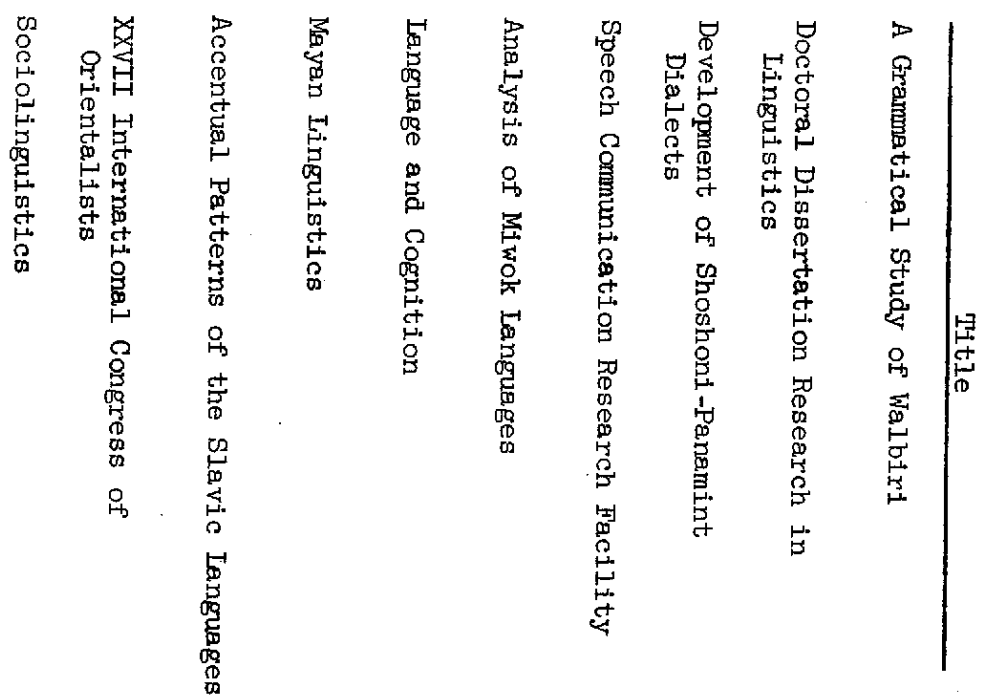

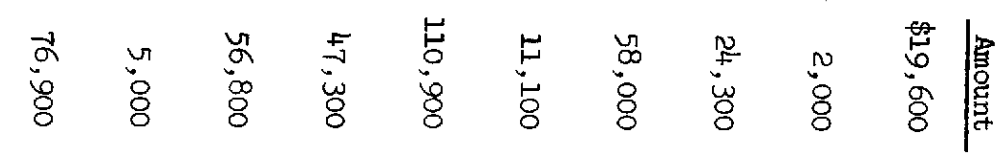

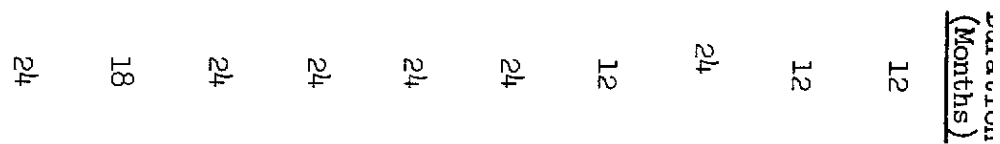




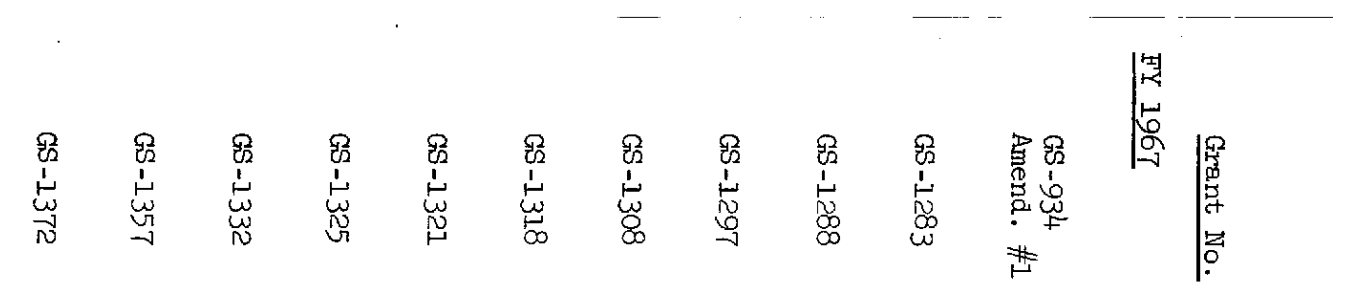

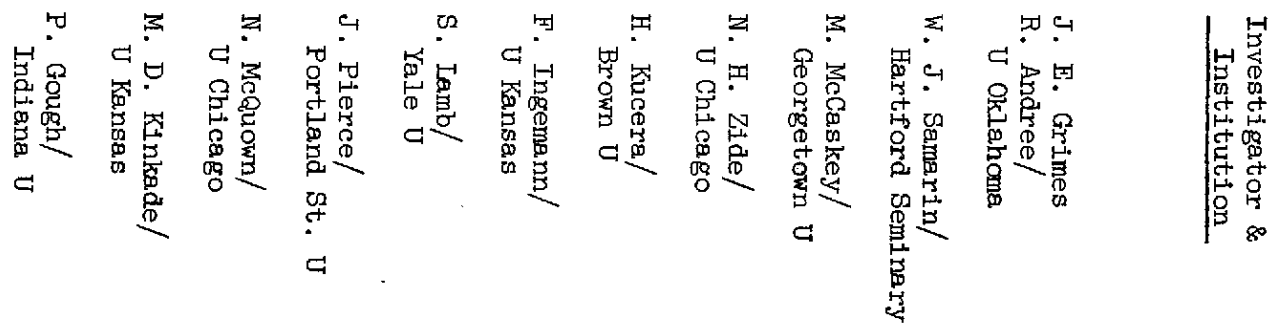

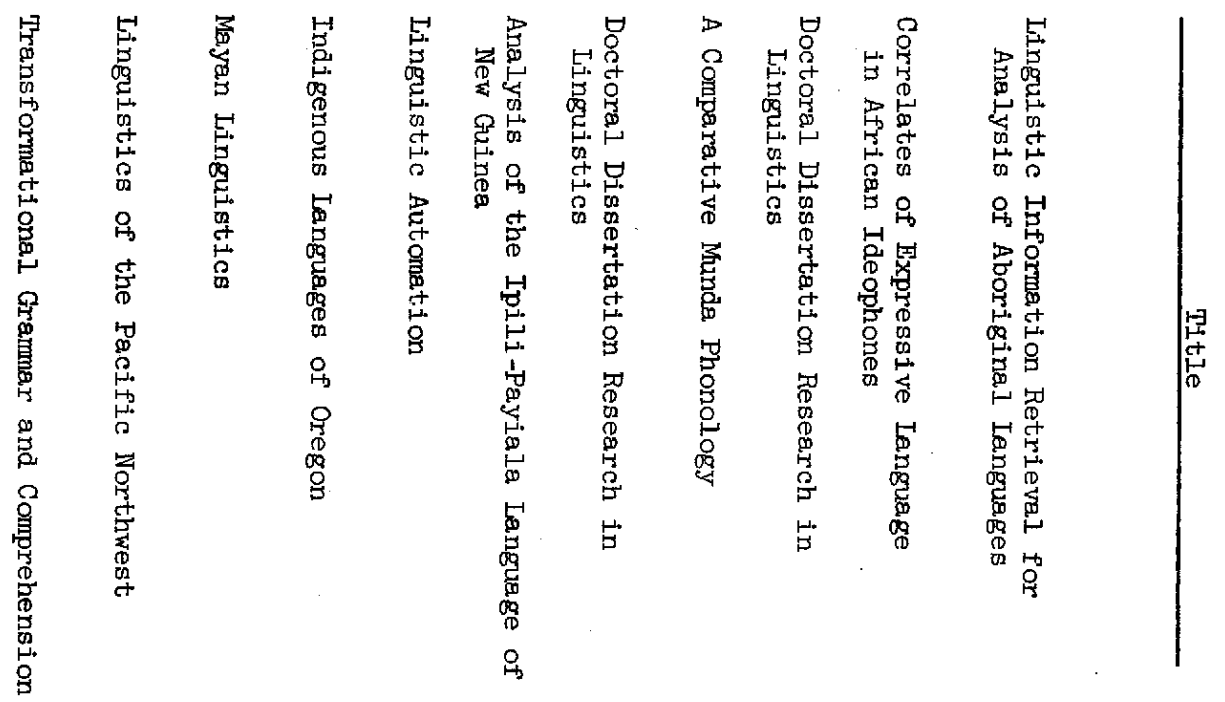

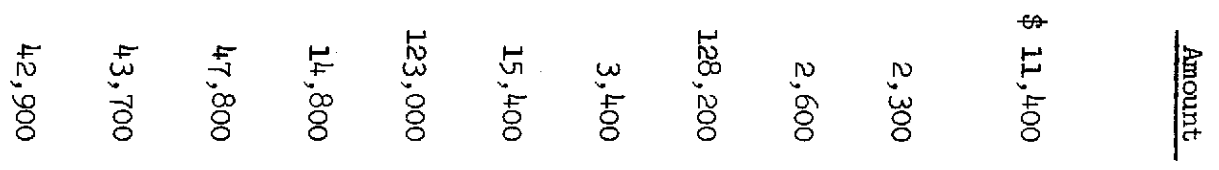

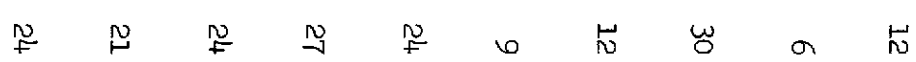

窟最 


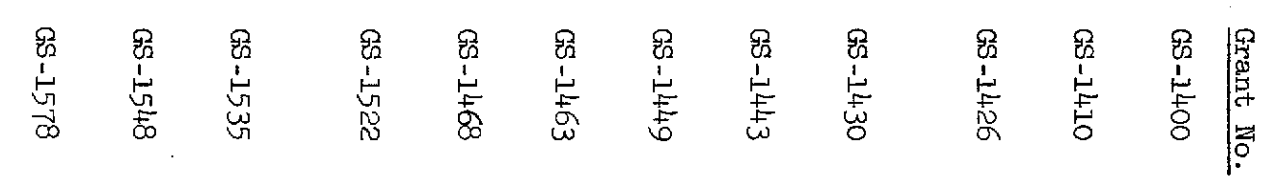

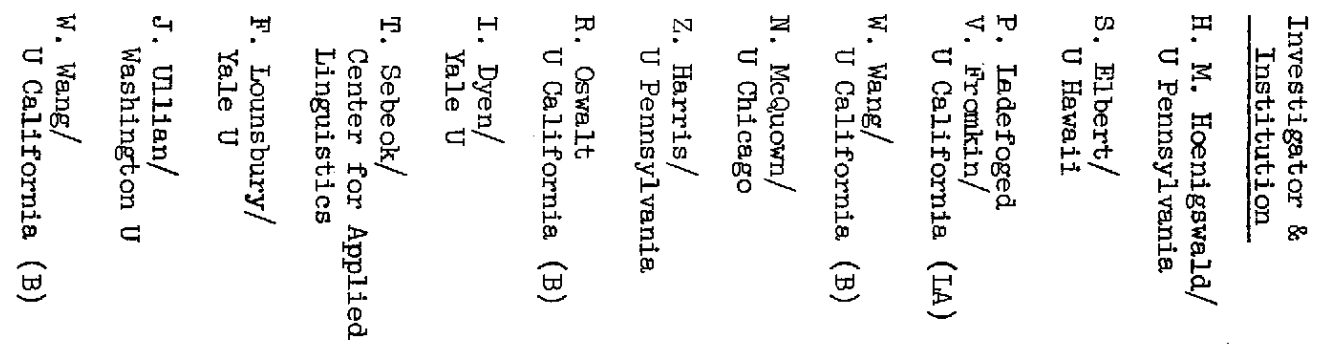

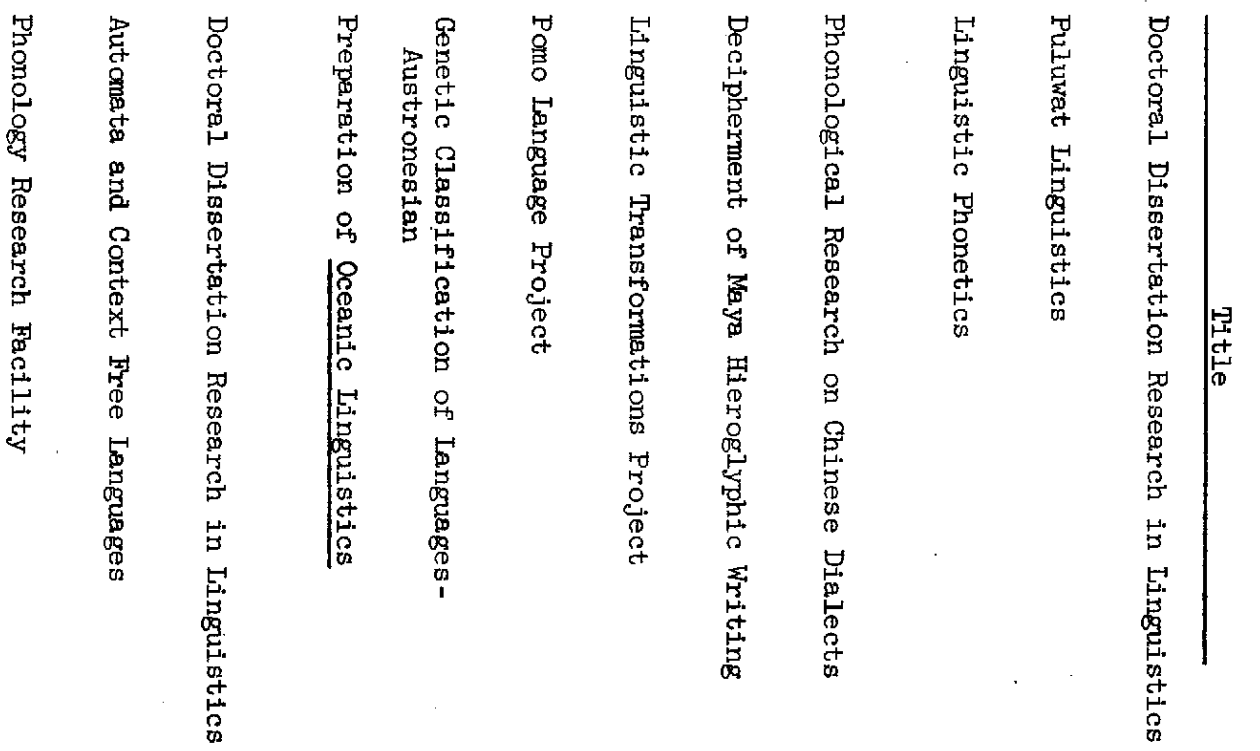

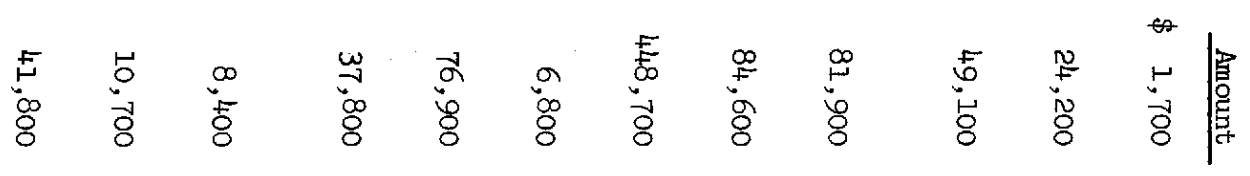

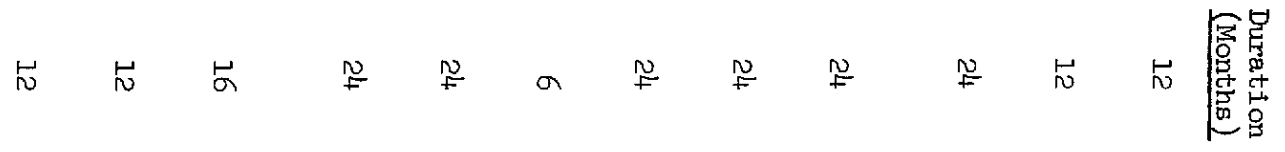




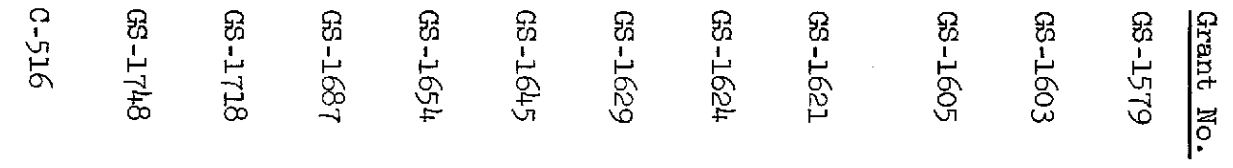

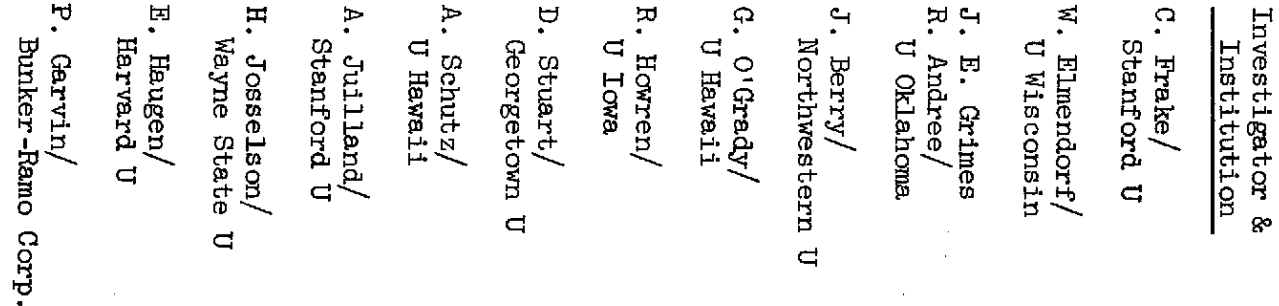

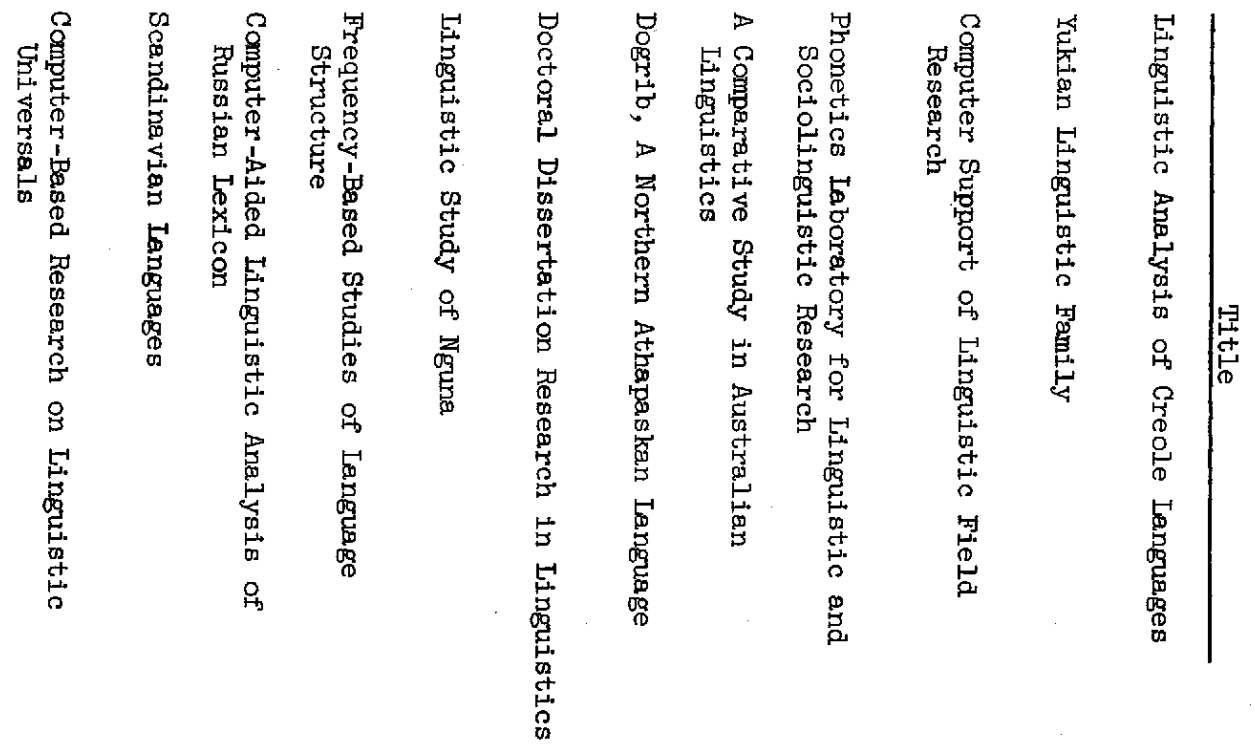

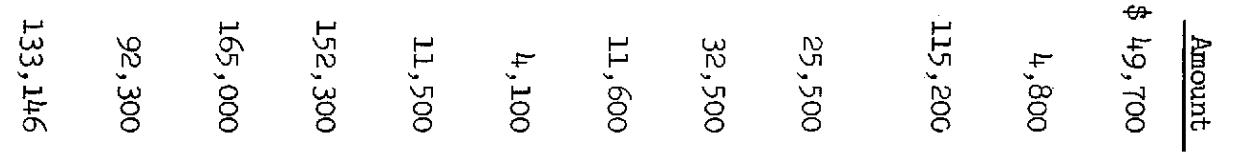

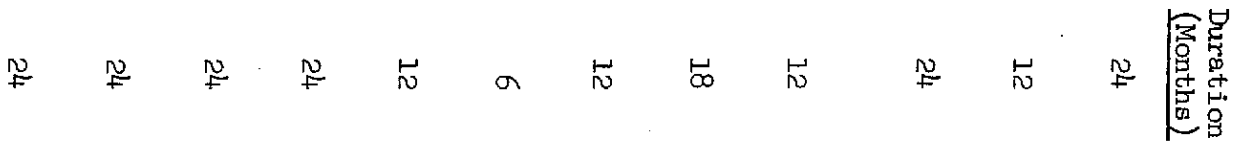




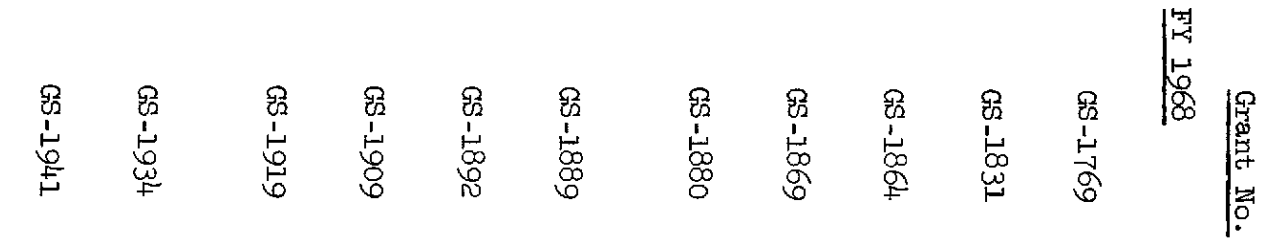

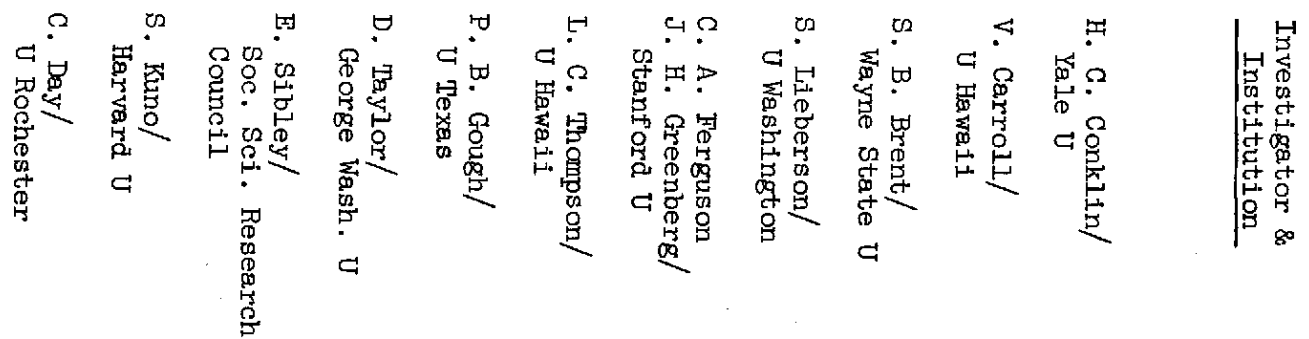

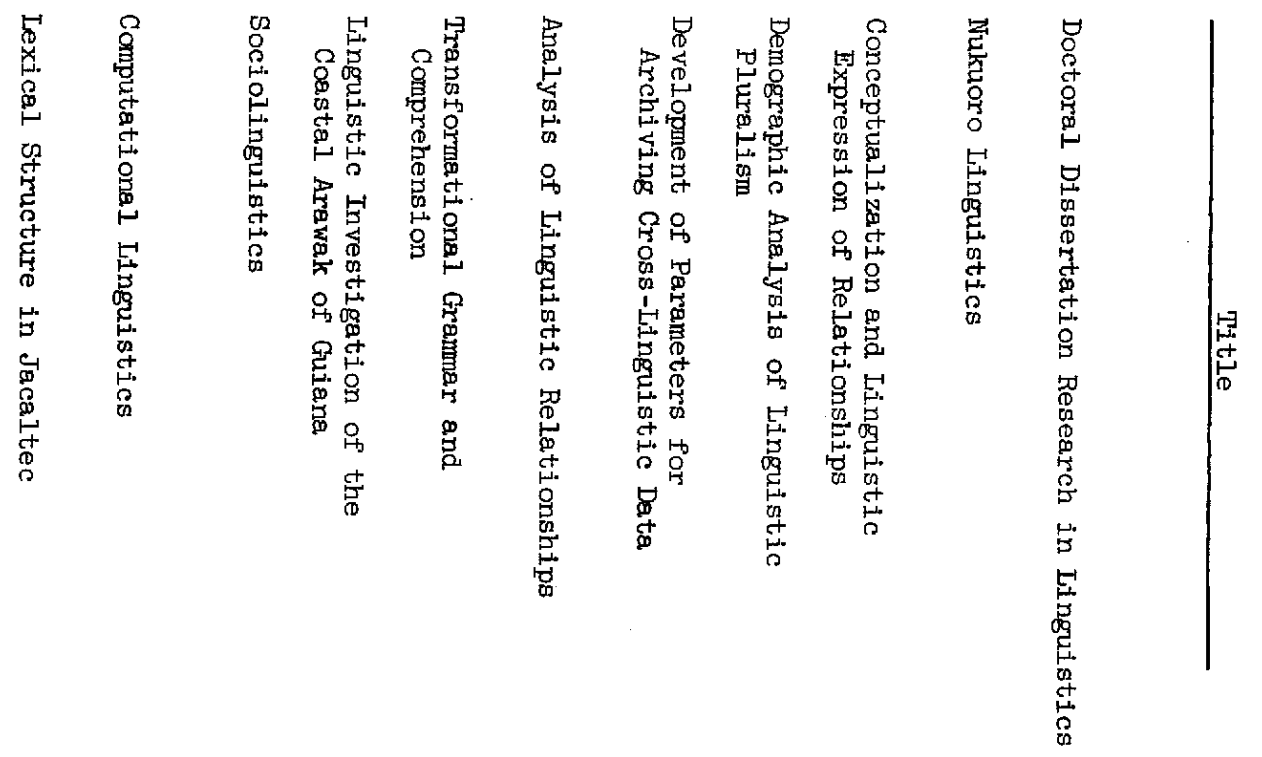

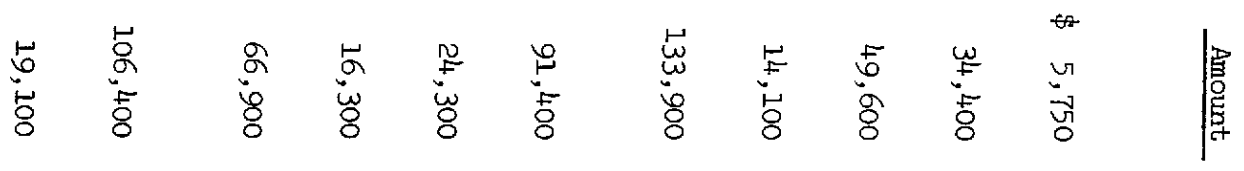

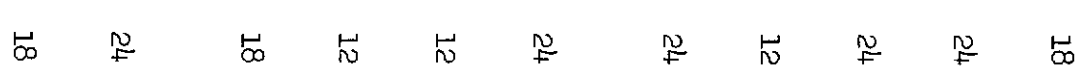

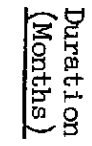




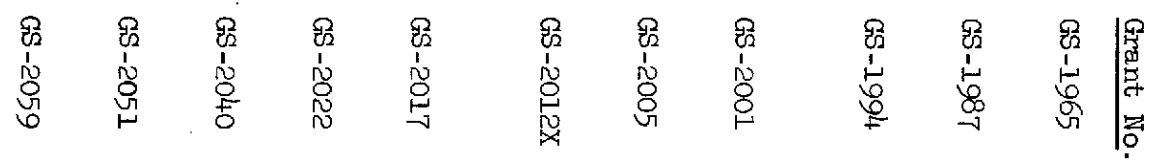

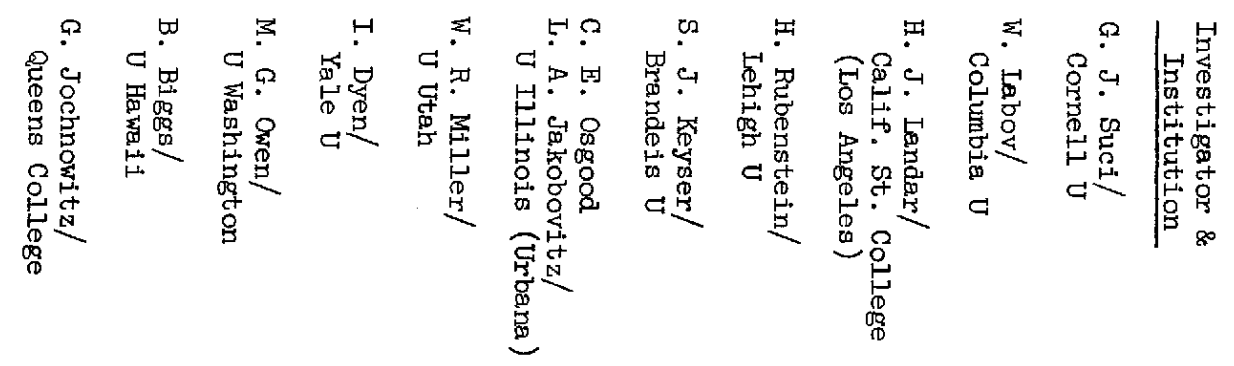

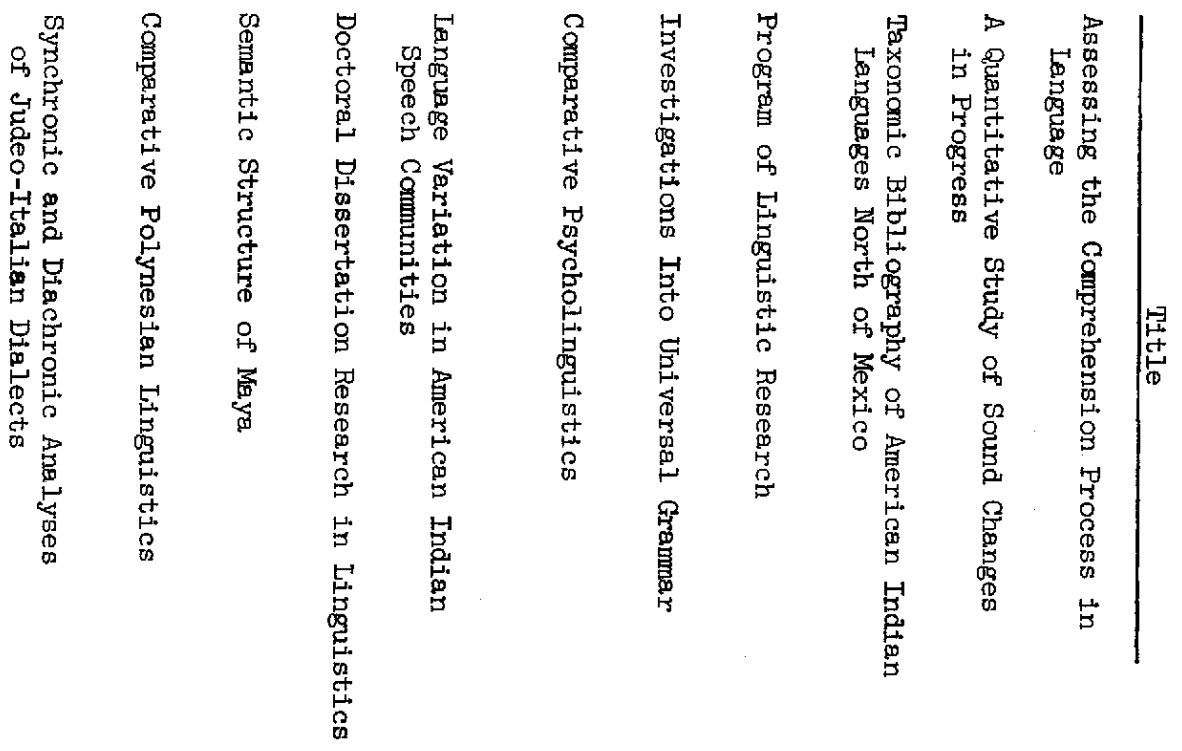

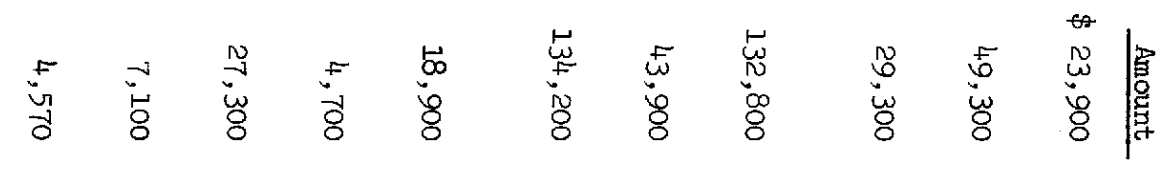

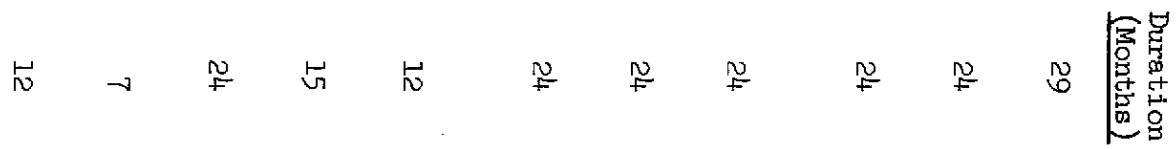




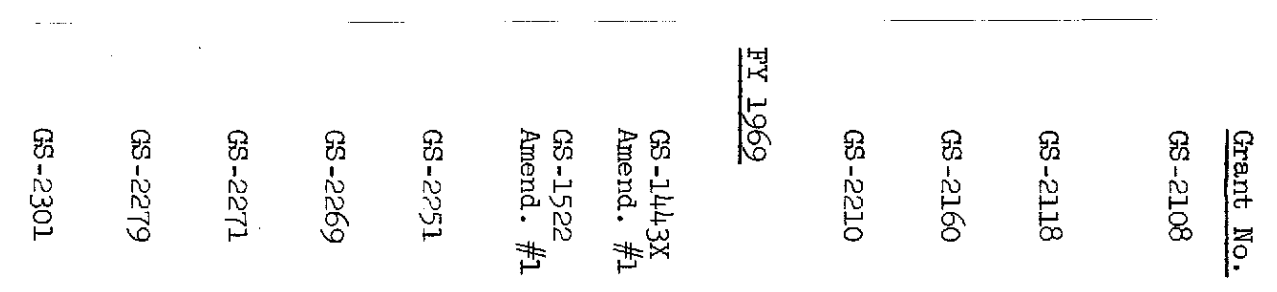

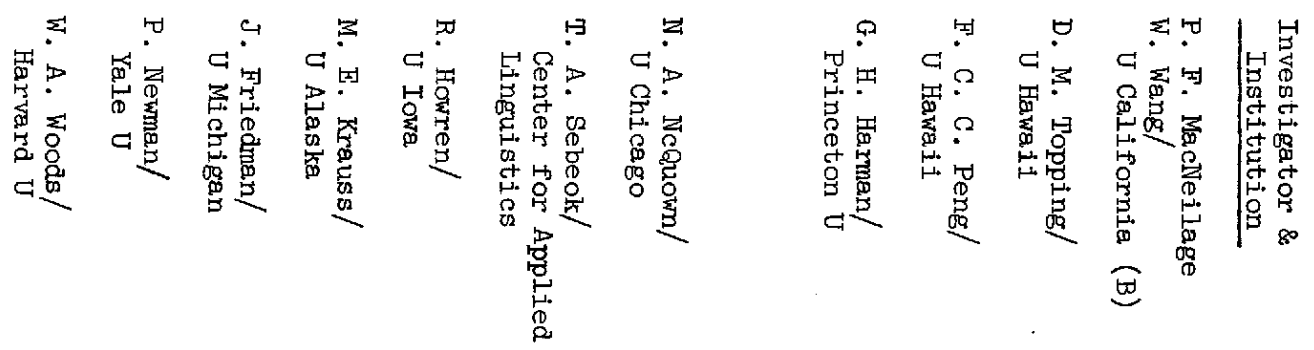

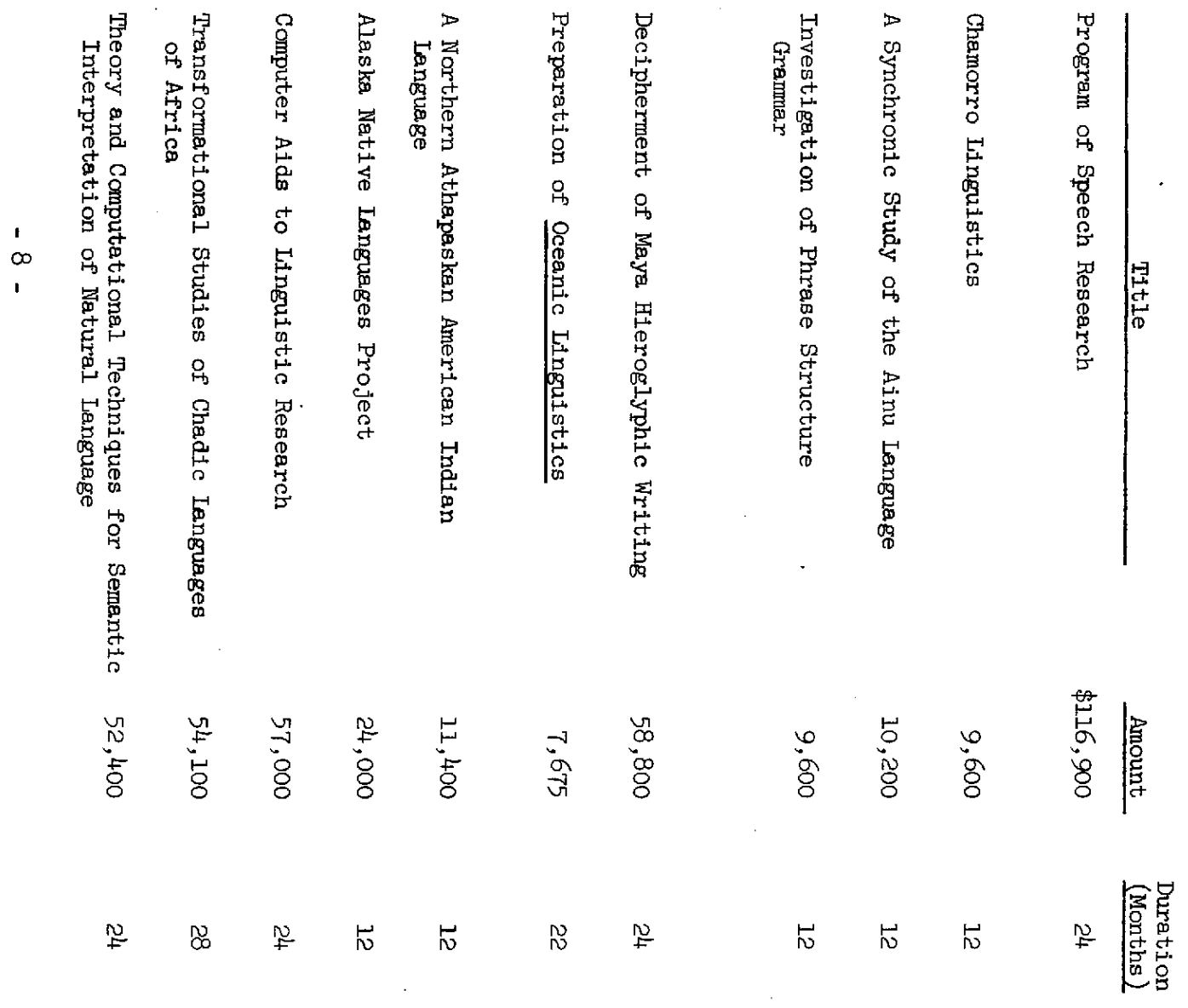




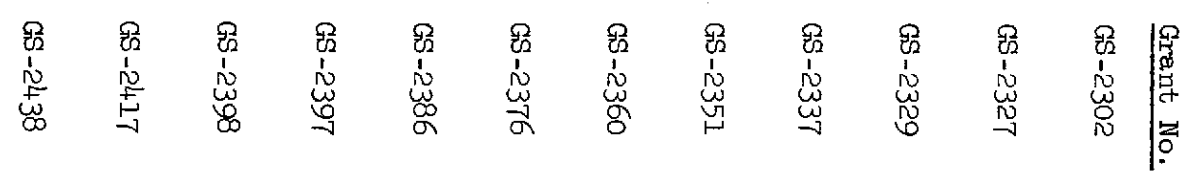

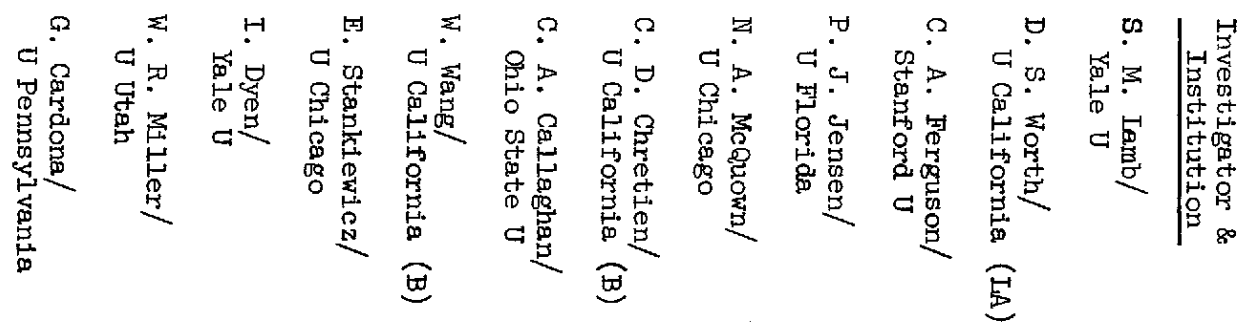

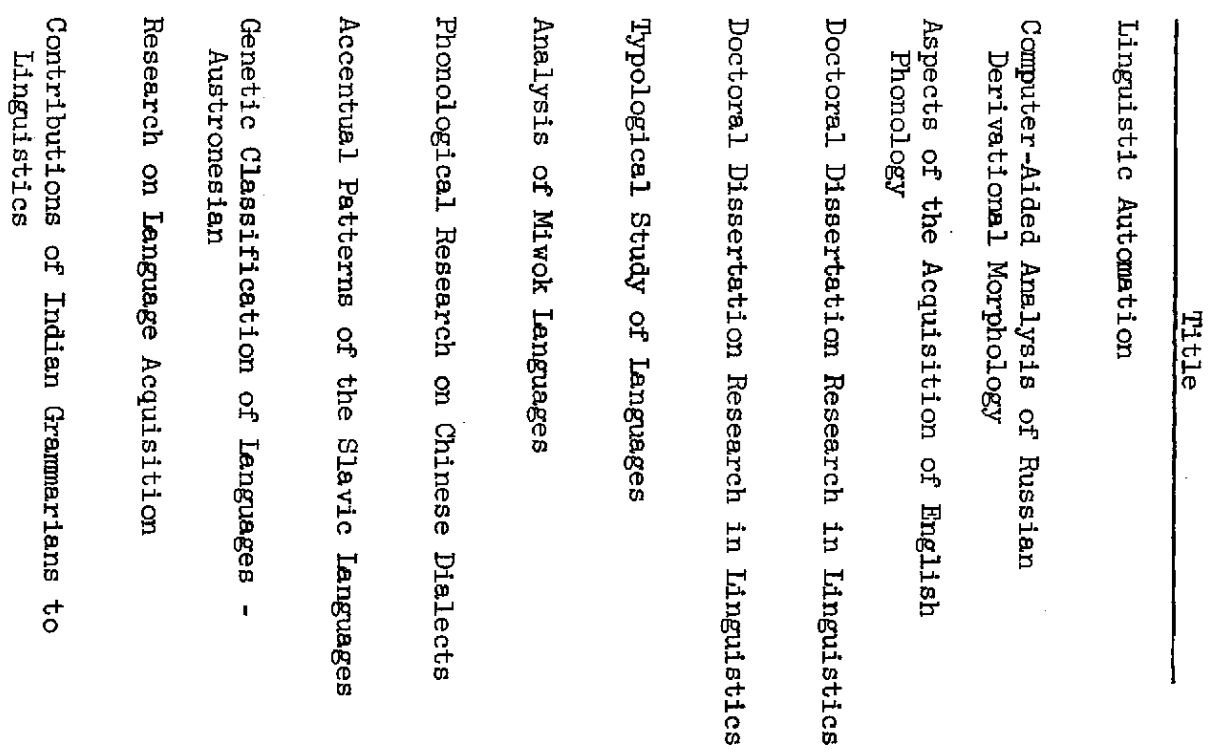

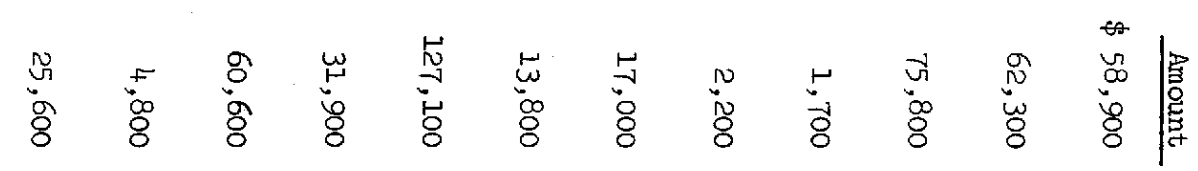

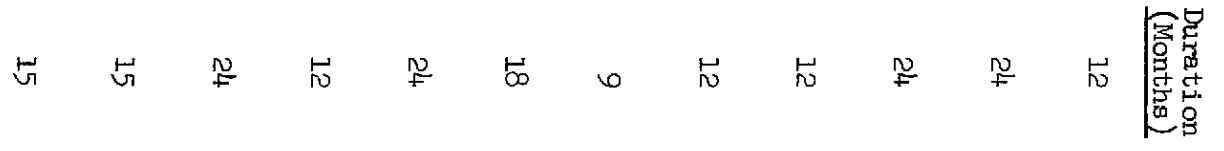




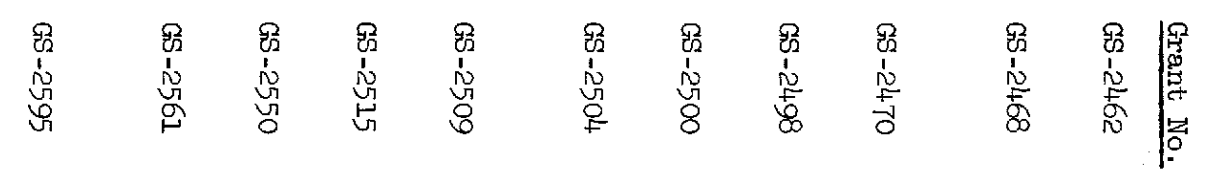

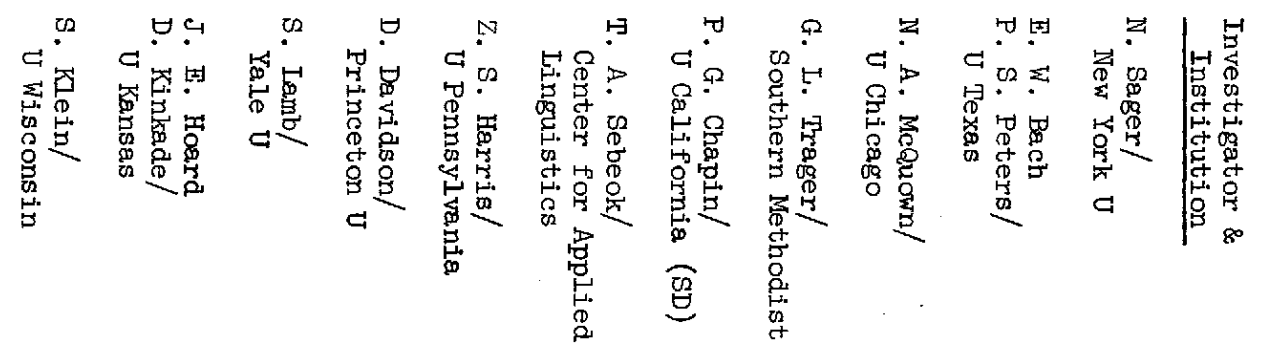

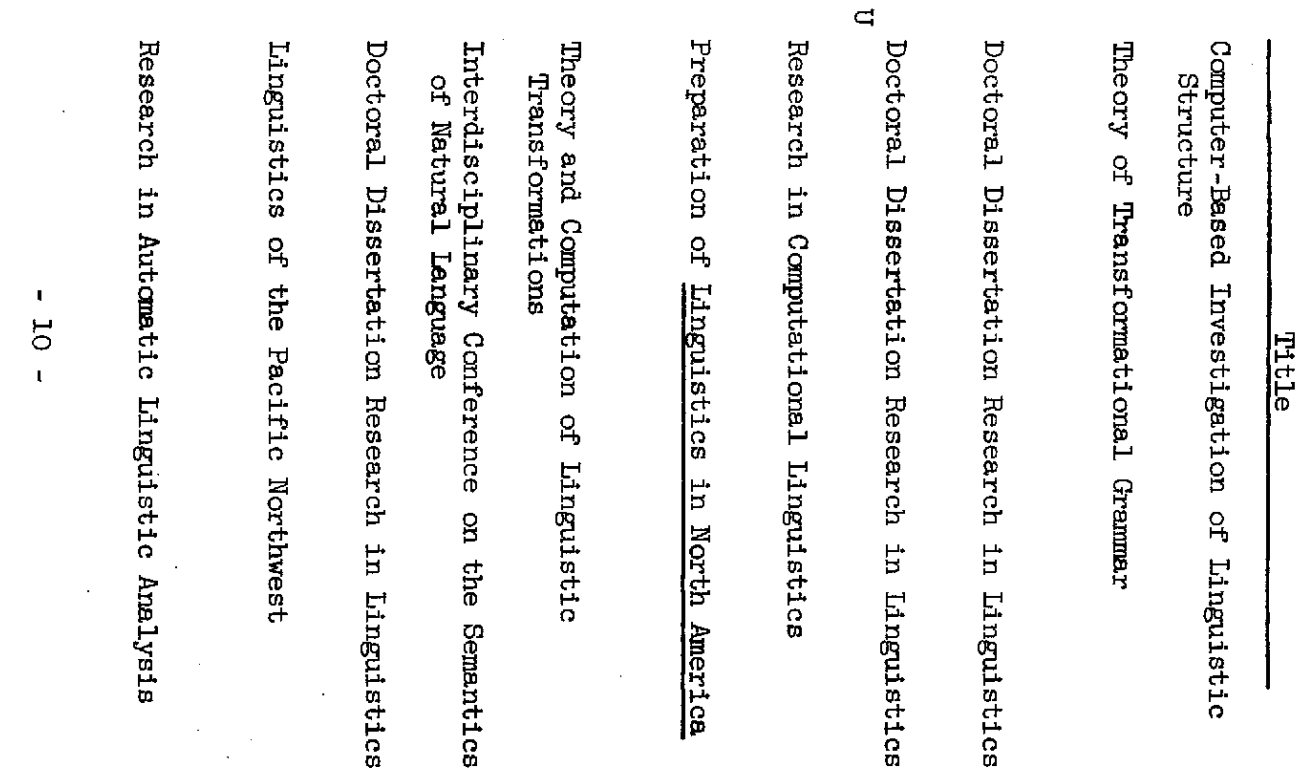

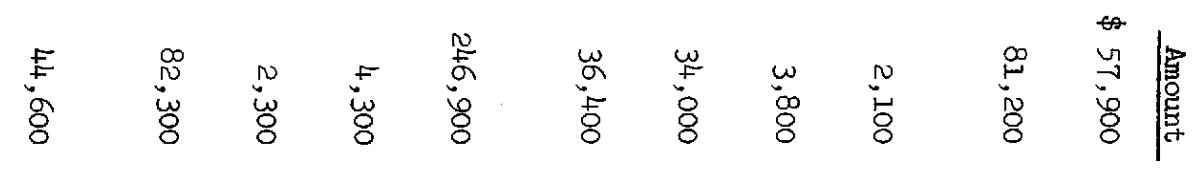

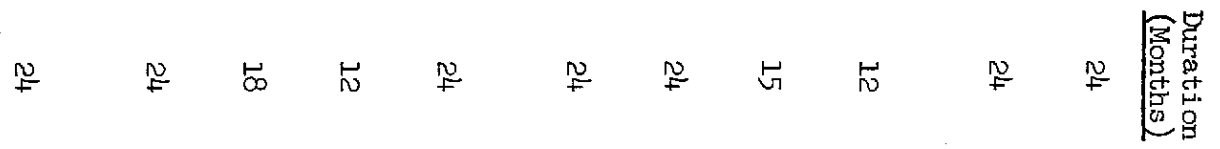




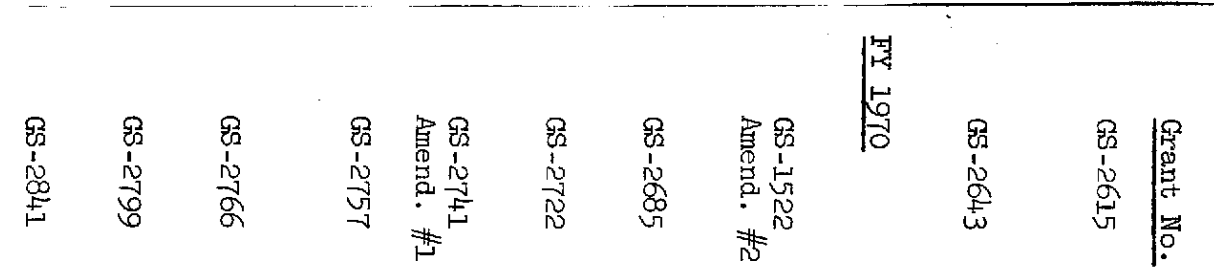

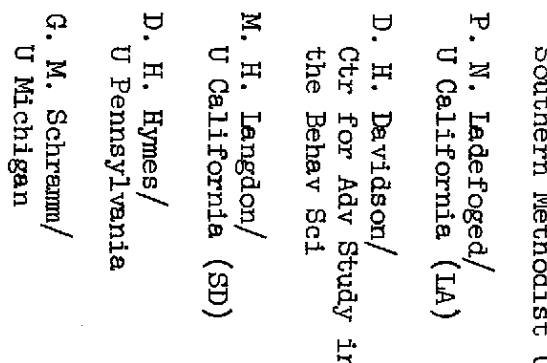

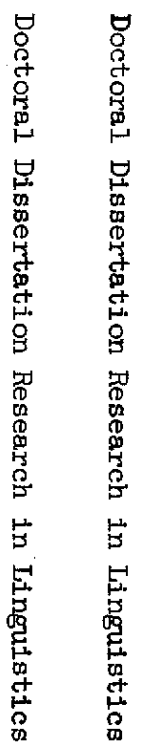
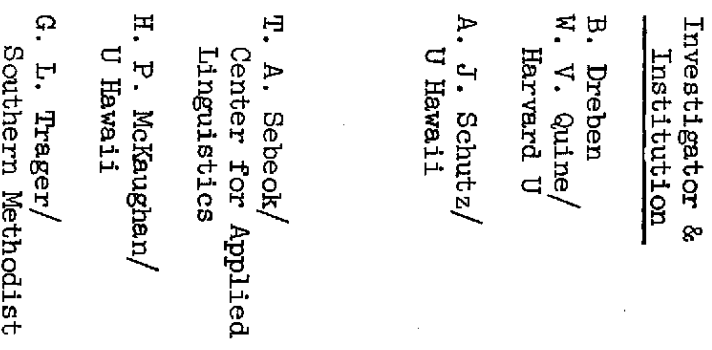

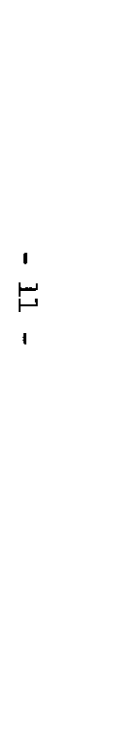

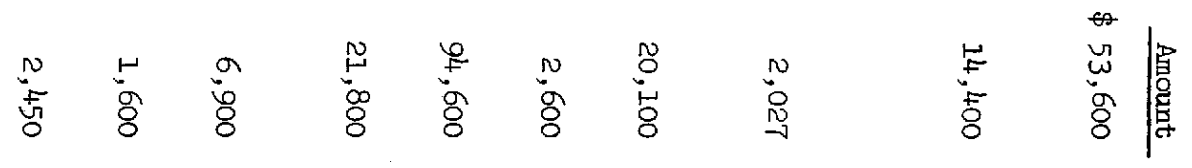

虫 


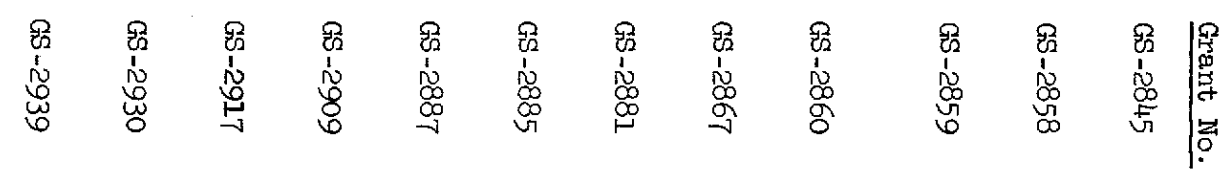

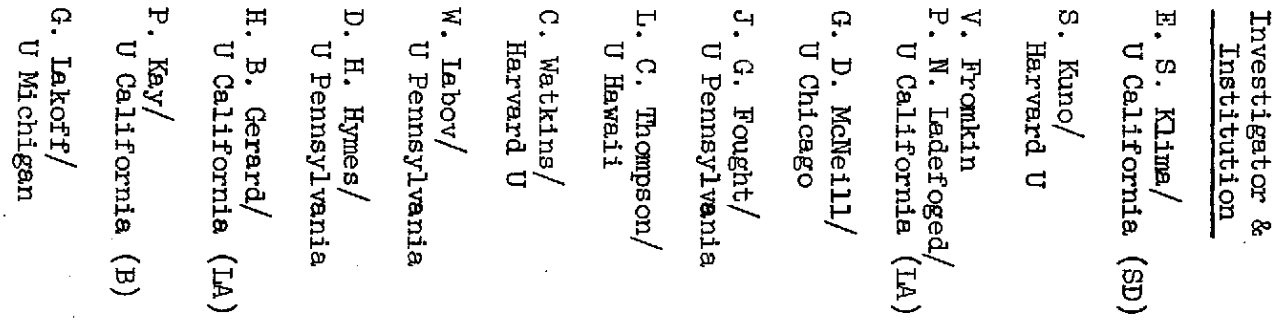

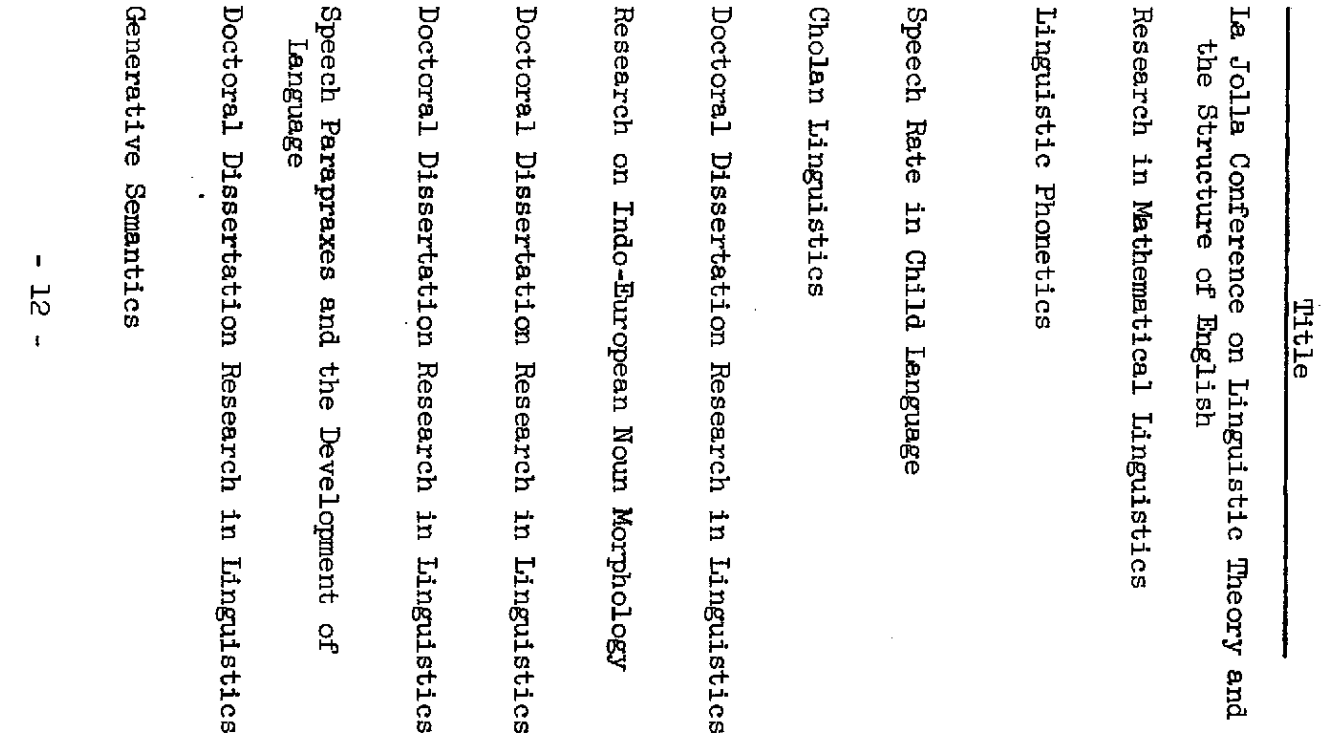

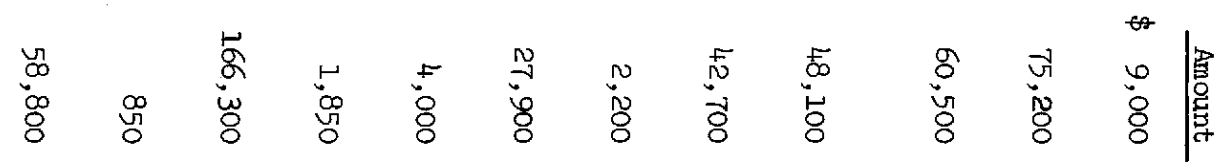

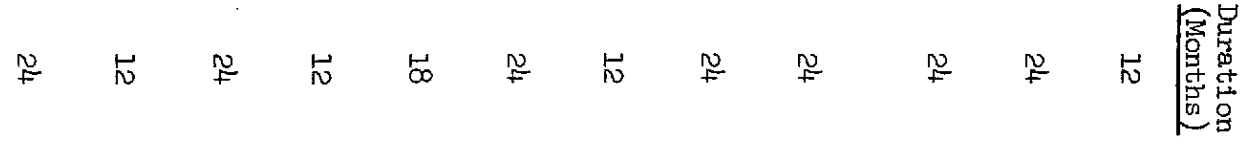




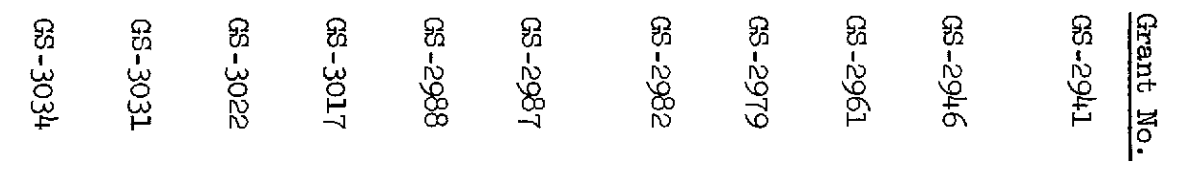

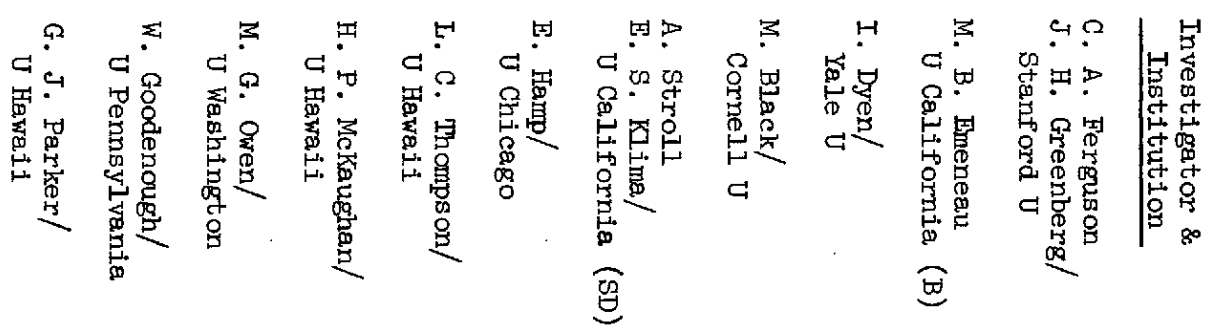

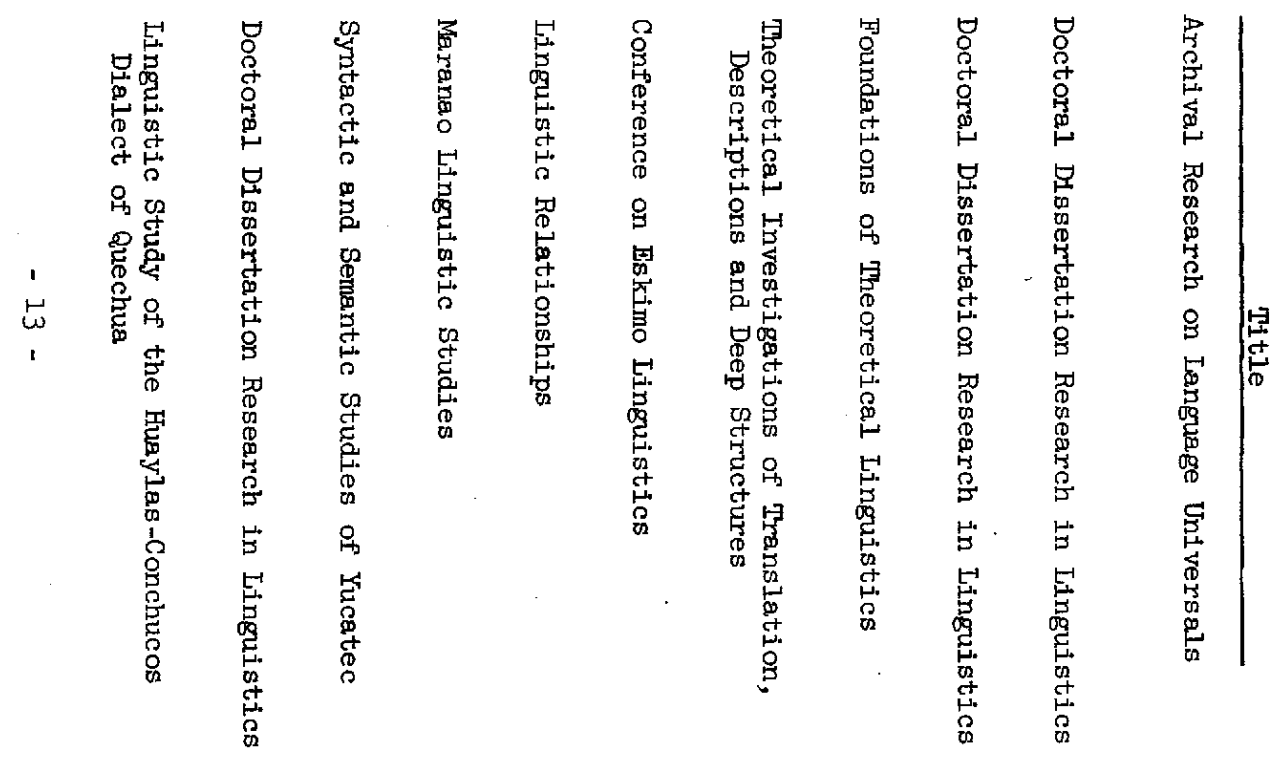

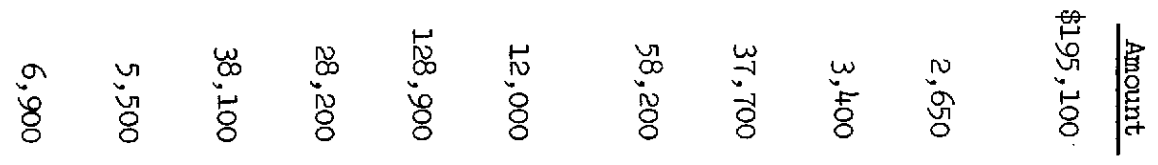

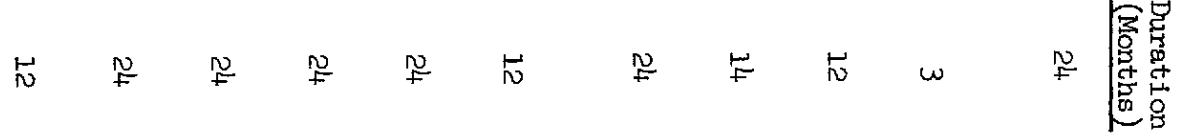




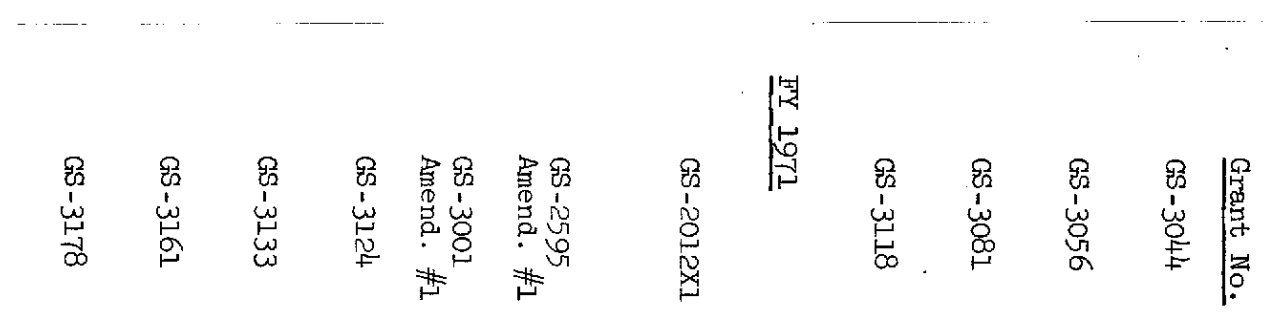

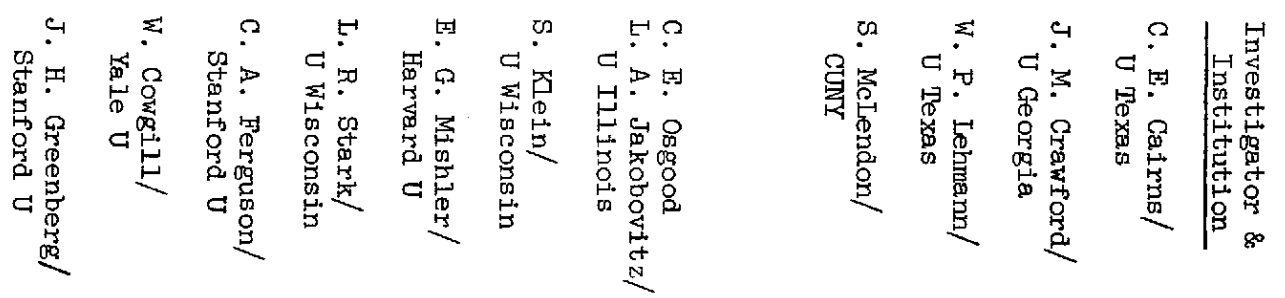

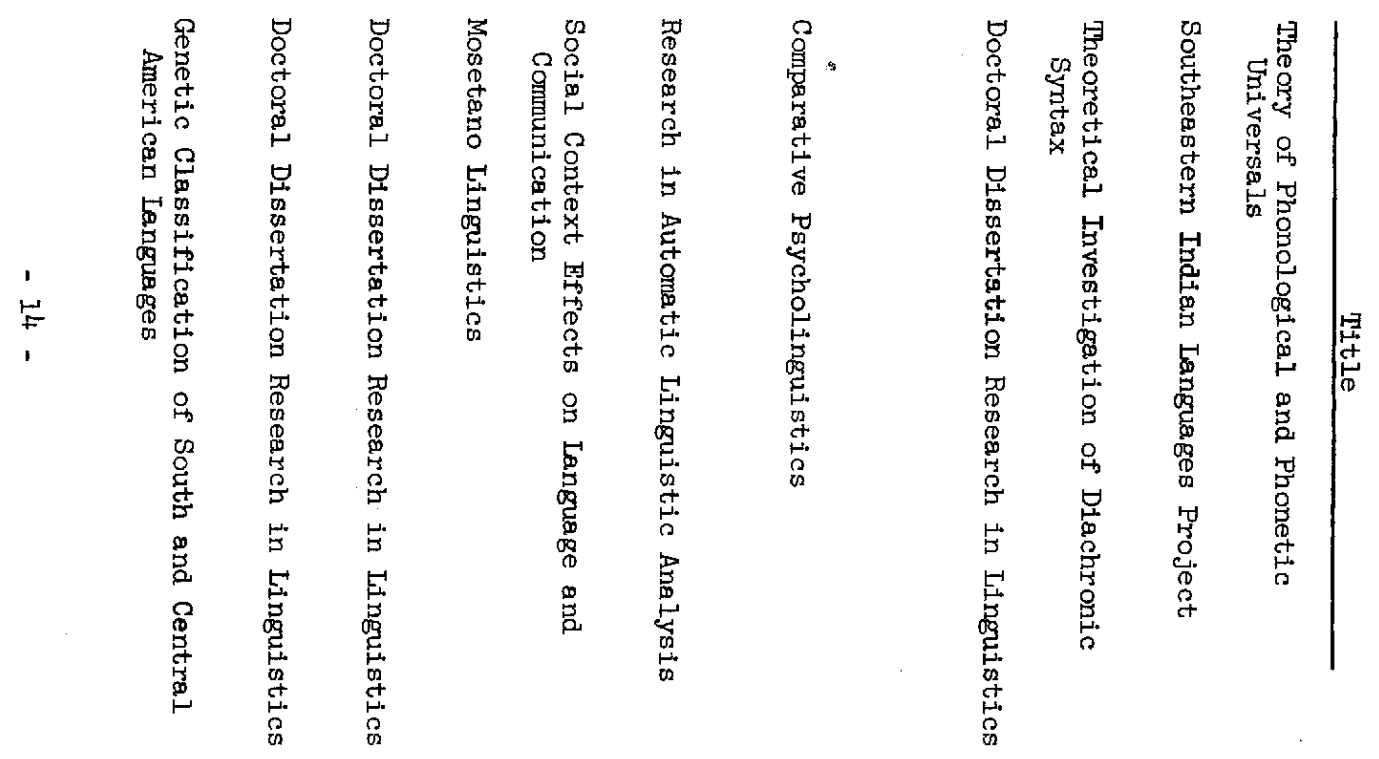

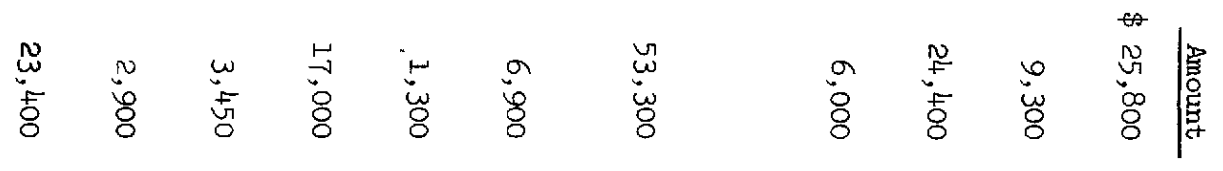

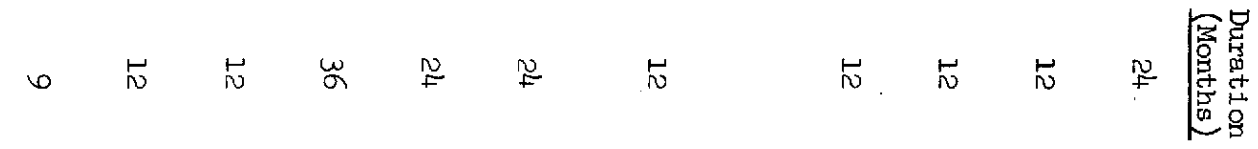




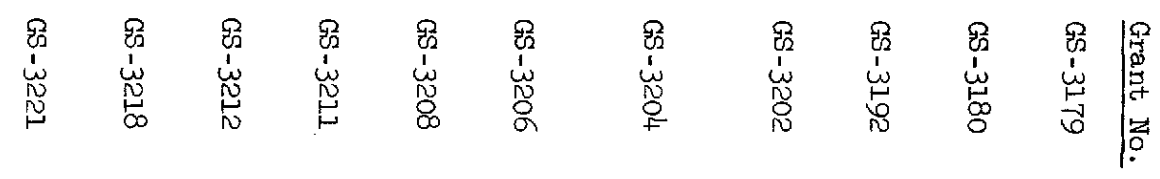

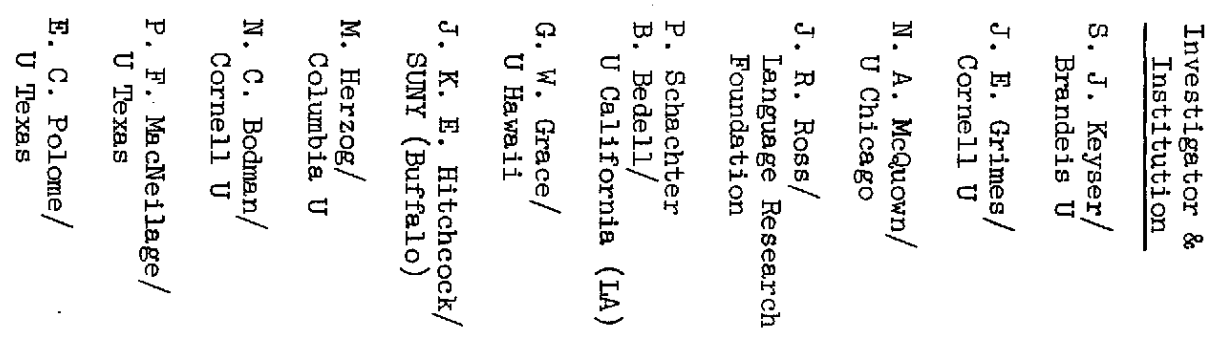

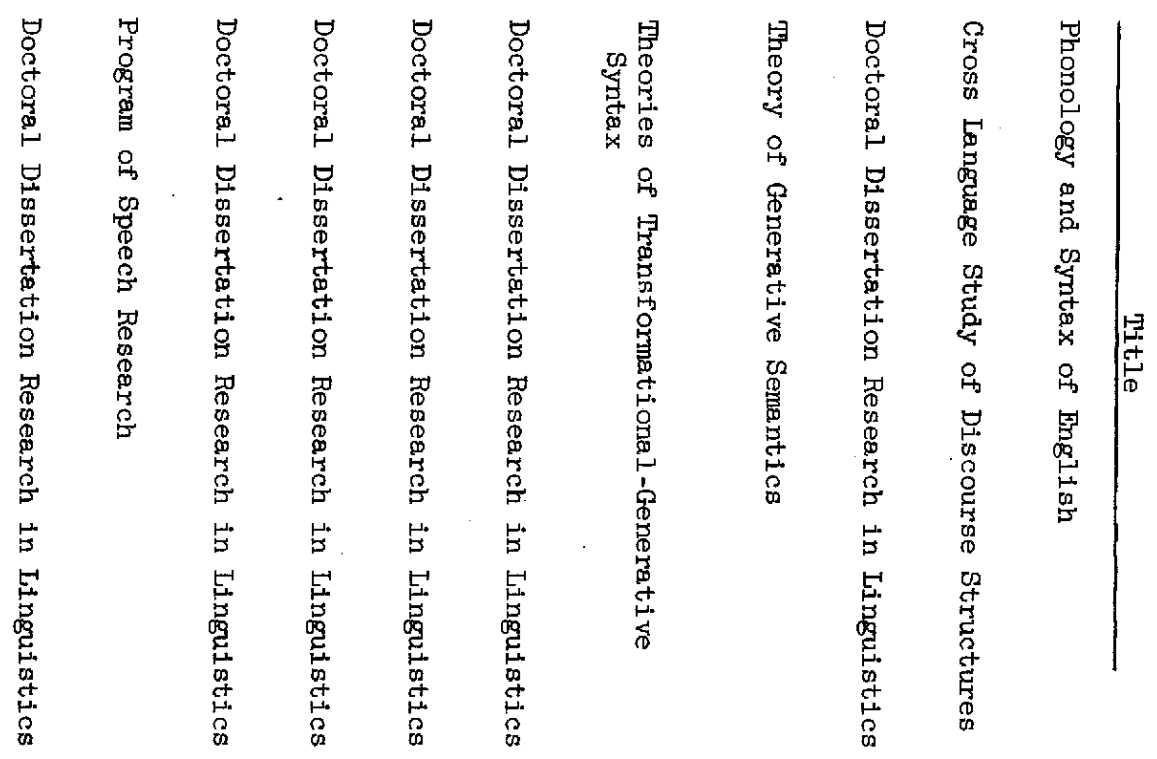

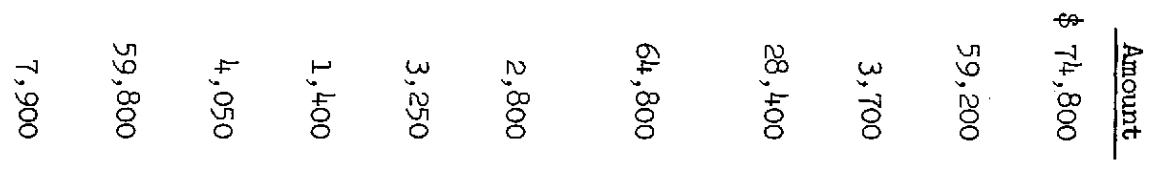

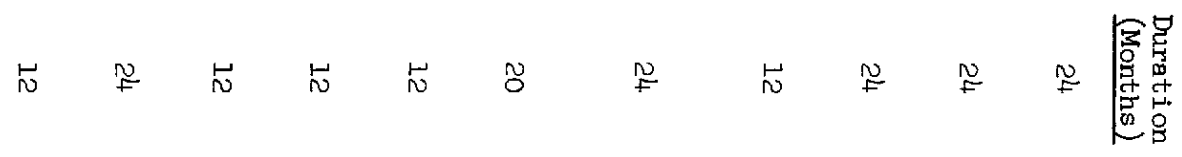




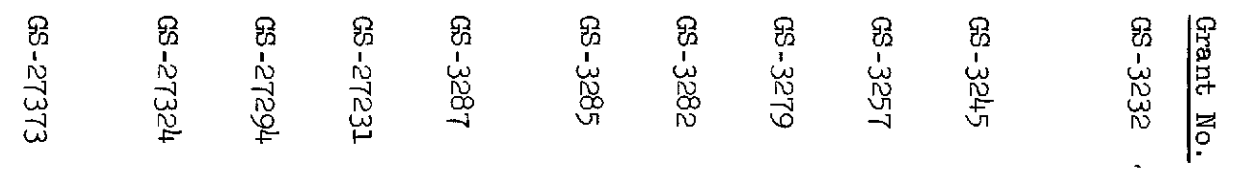

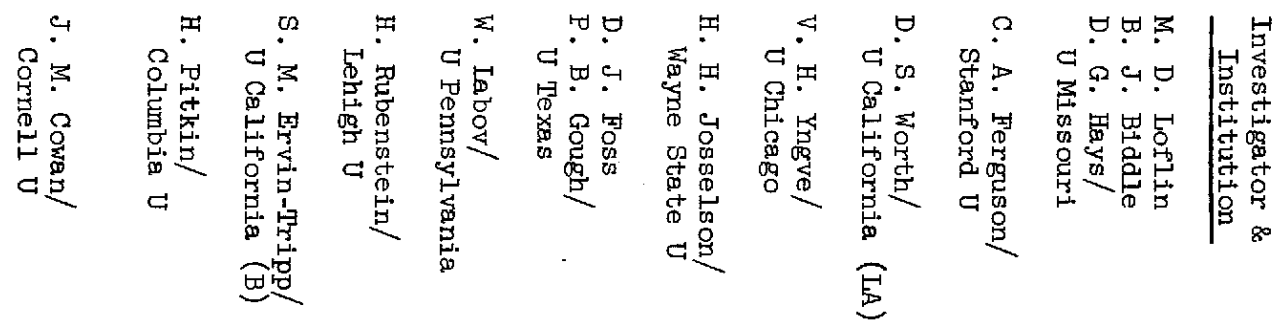

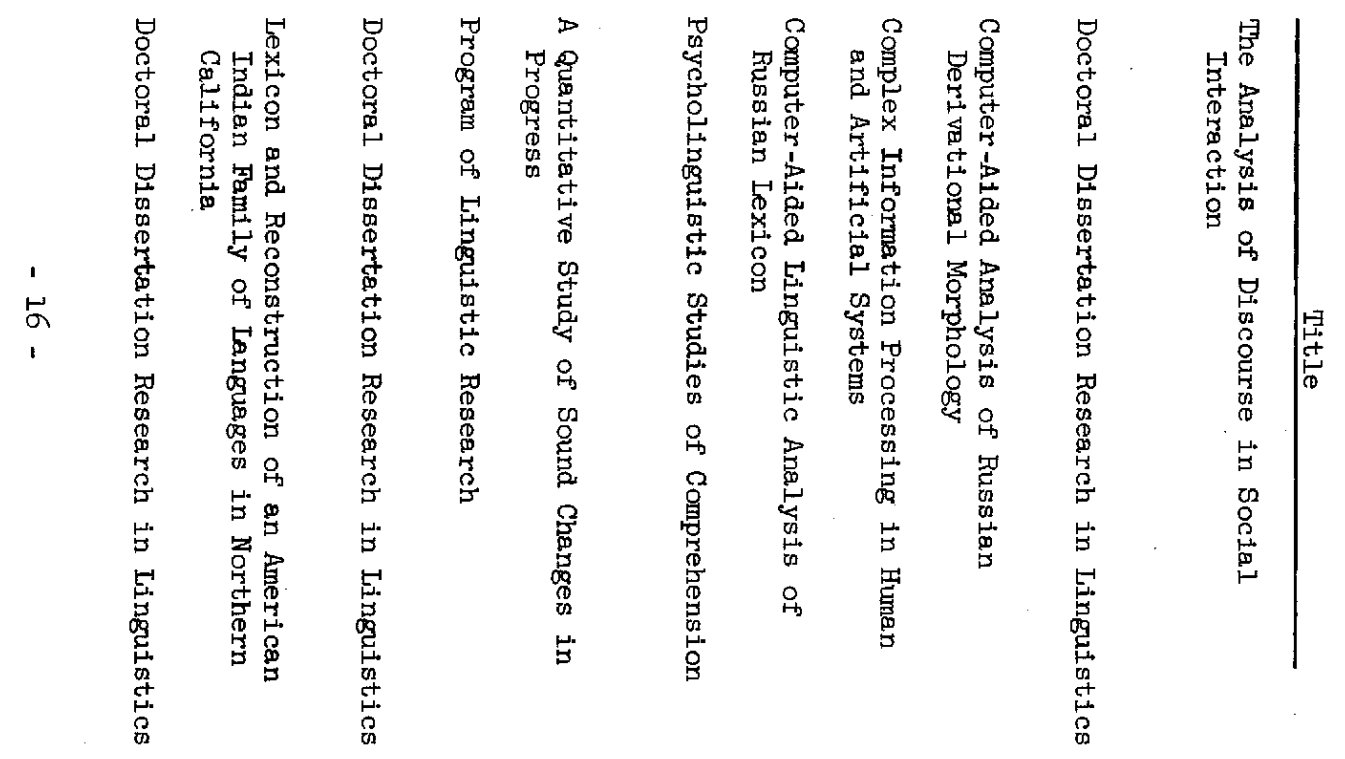

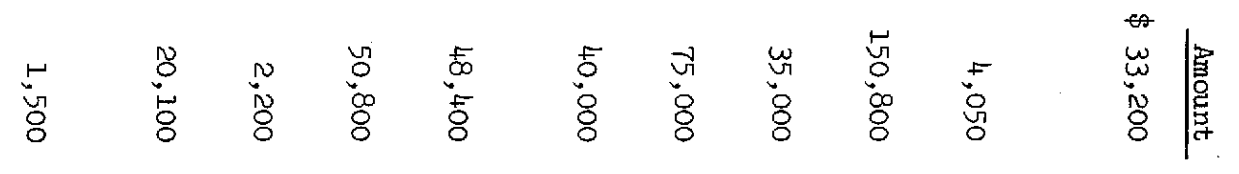

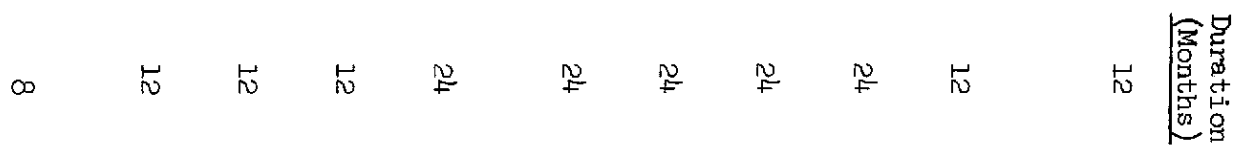




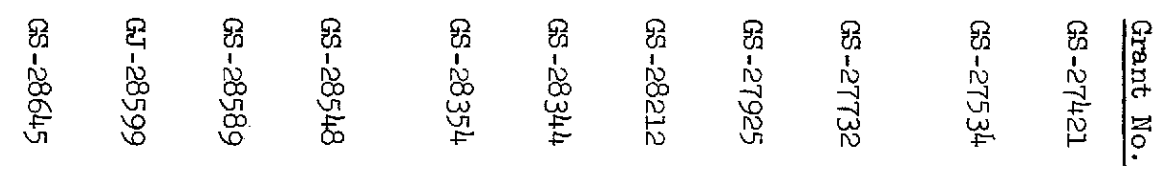

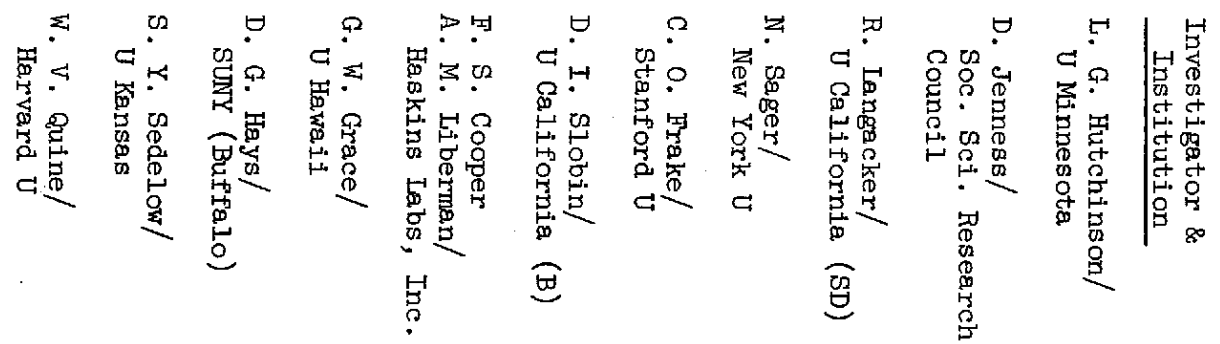

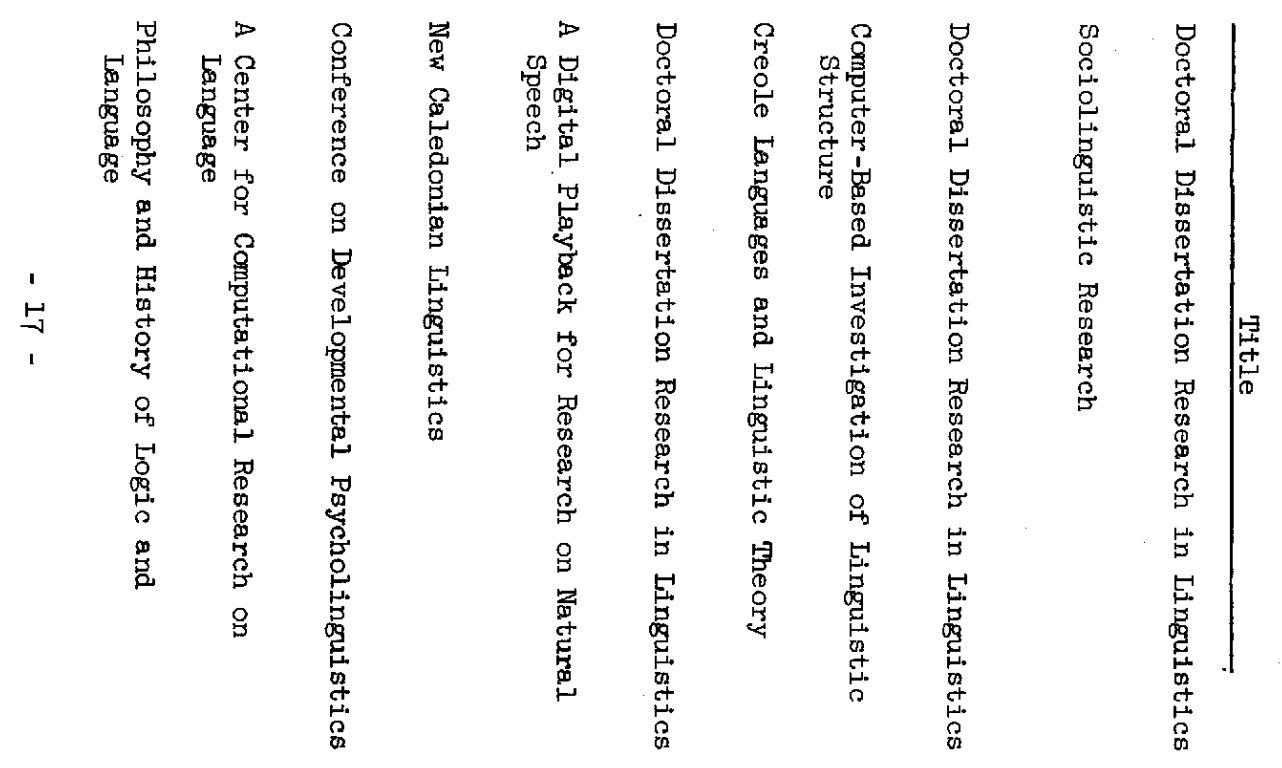

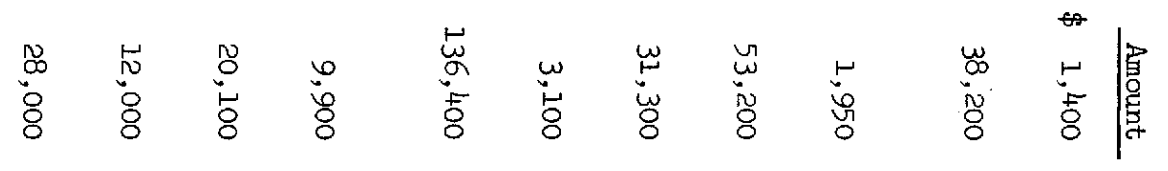

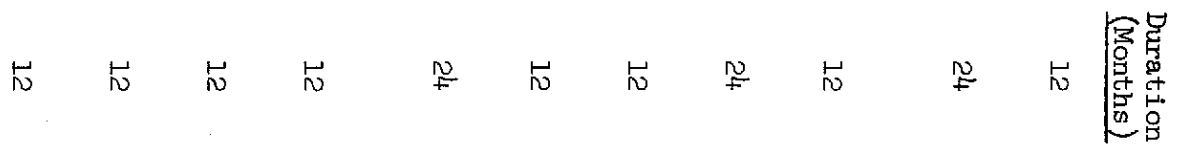




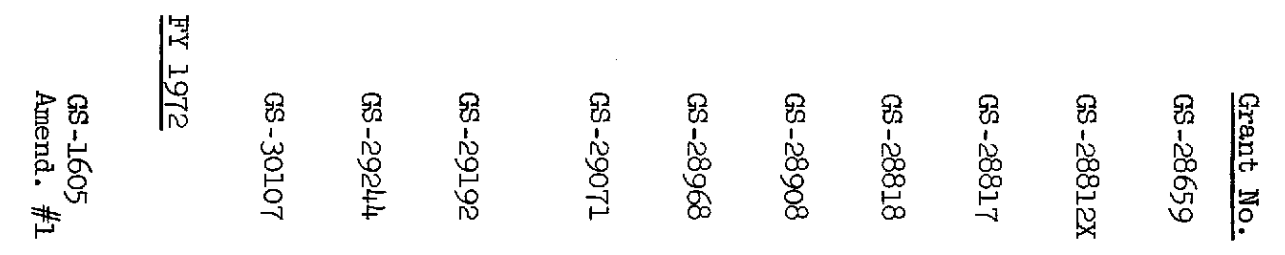

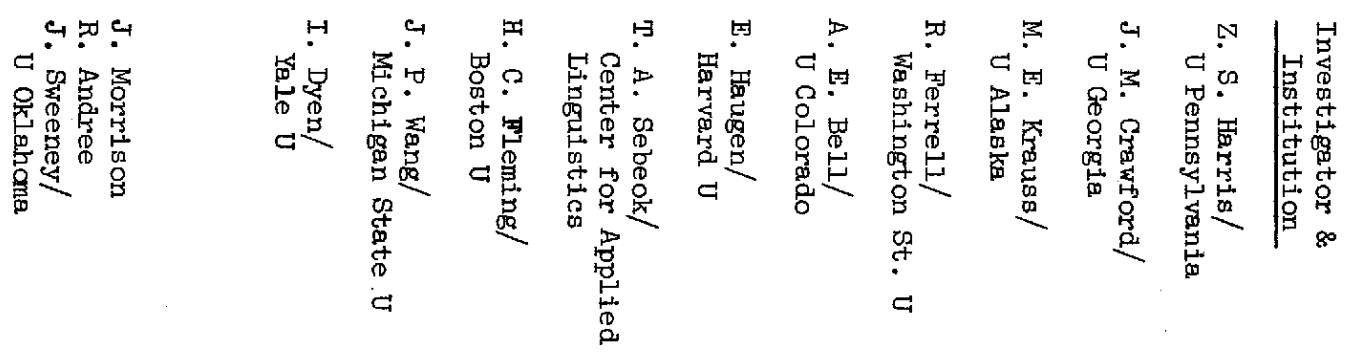

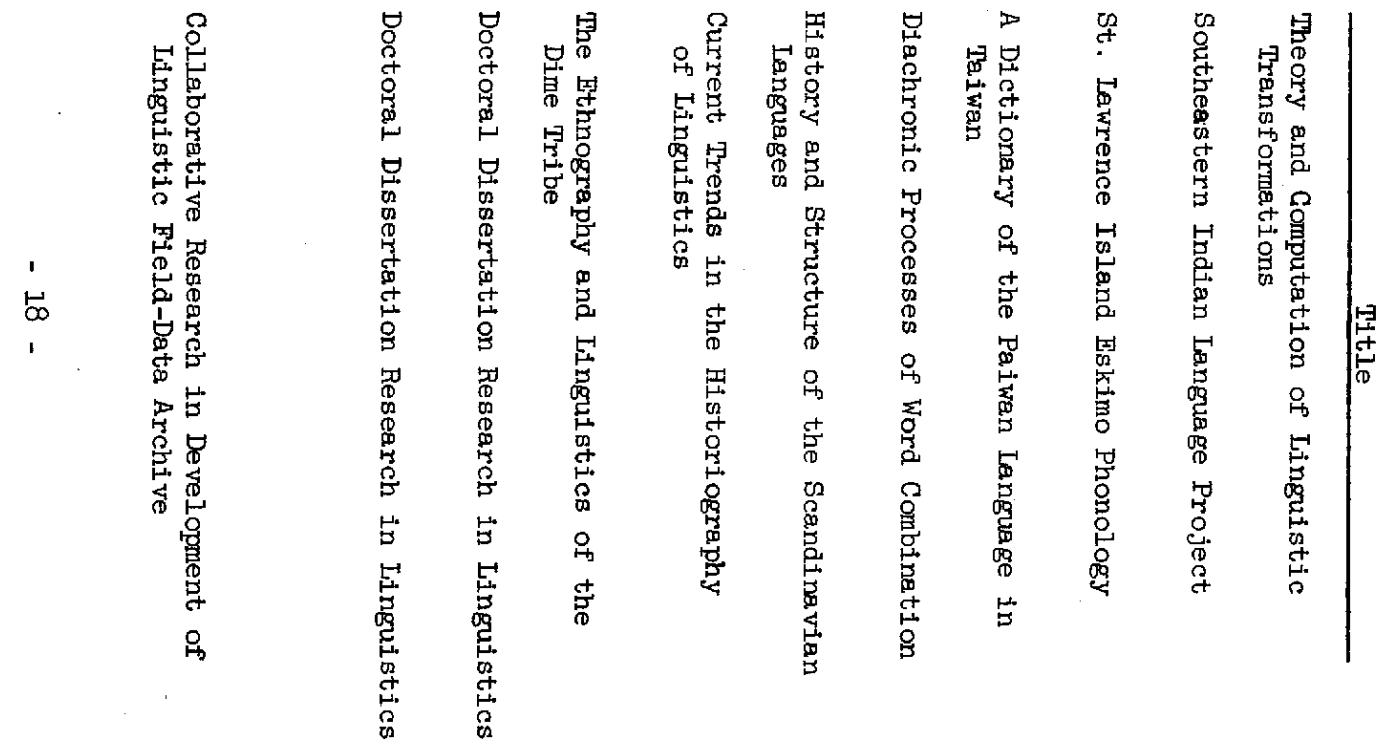

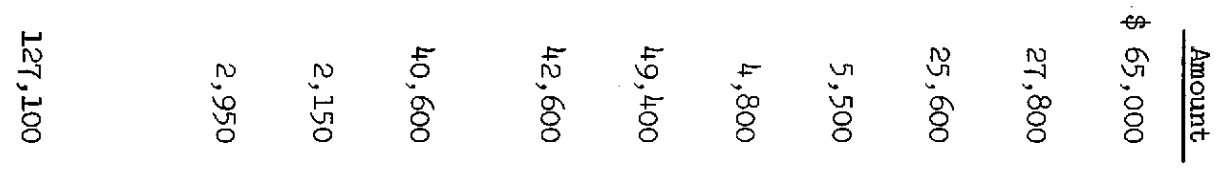

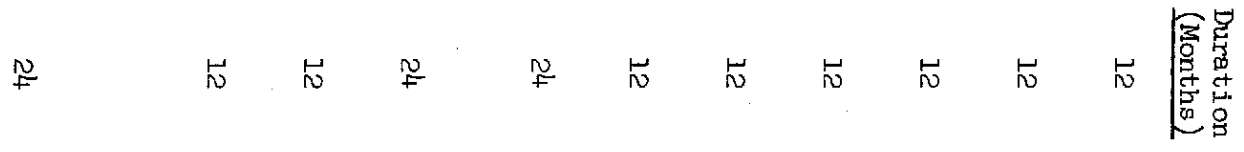




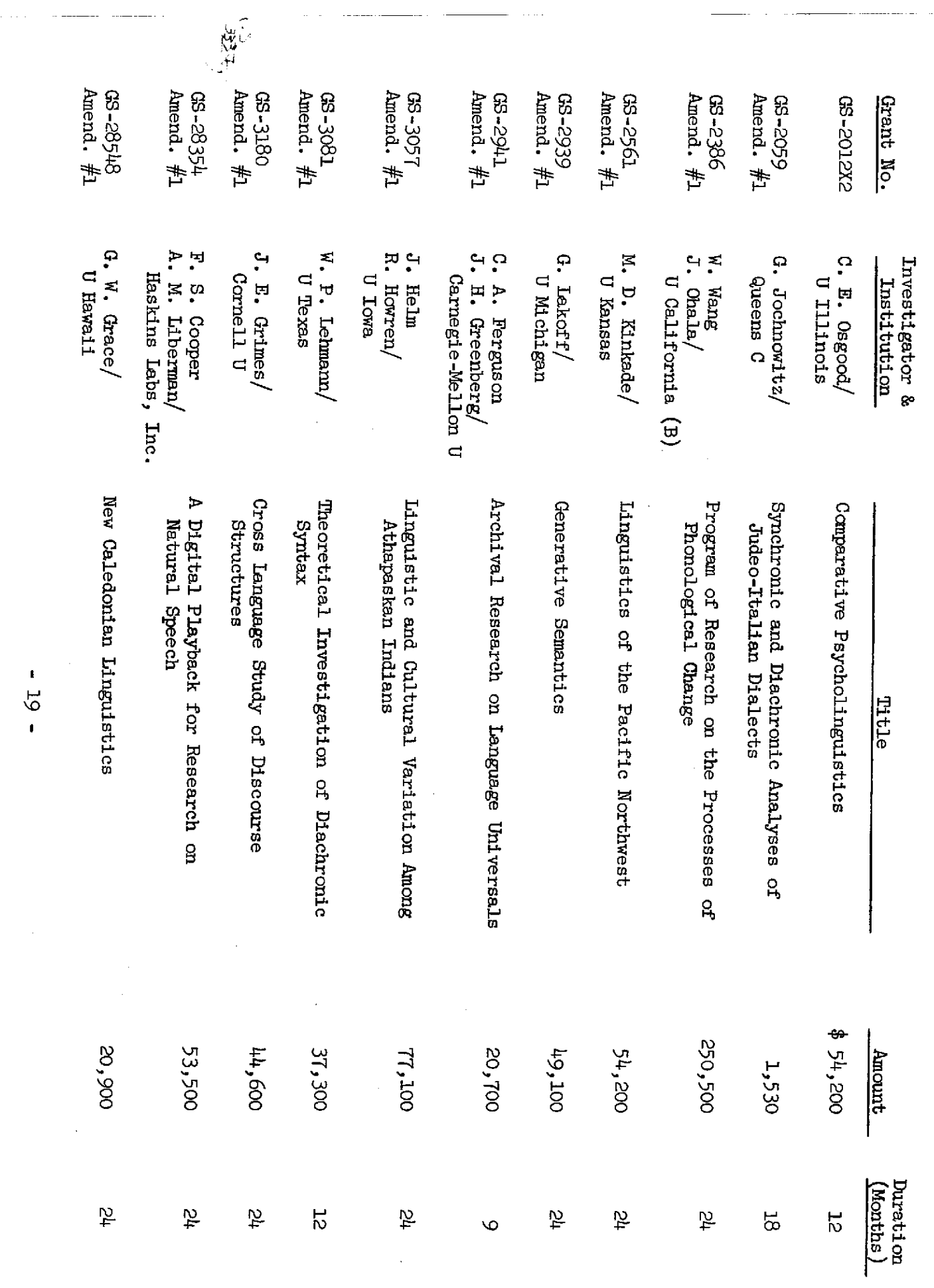




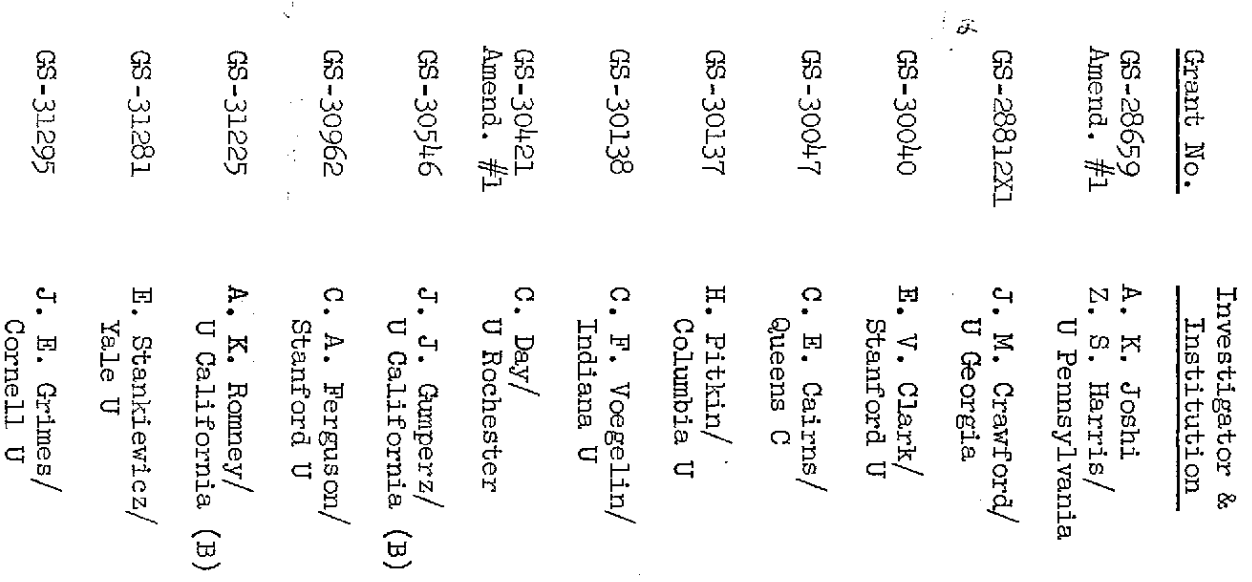

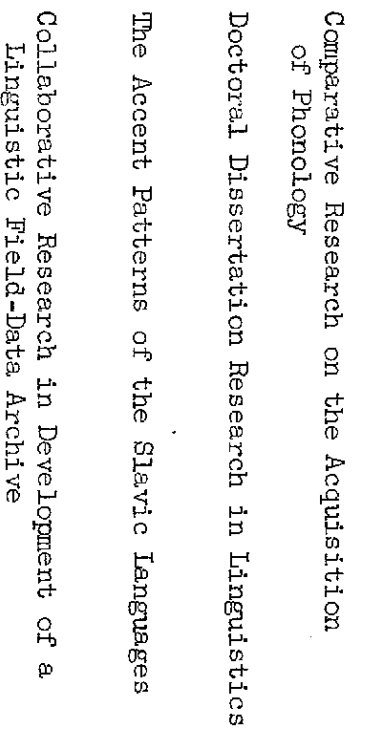
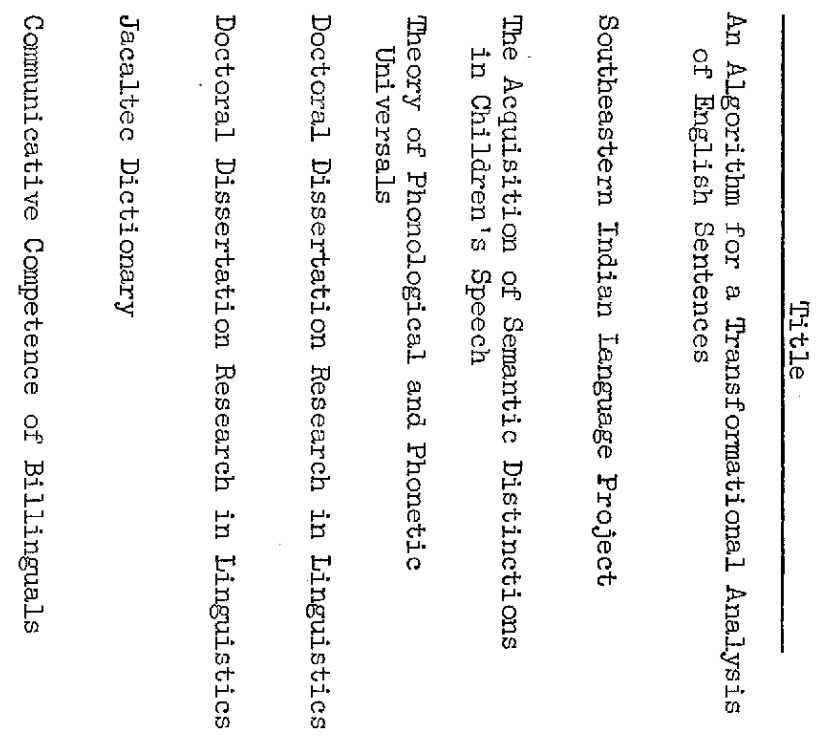

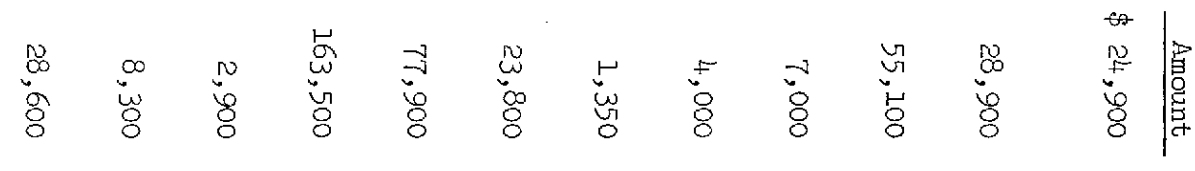

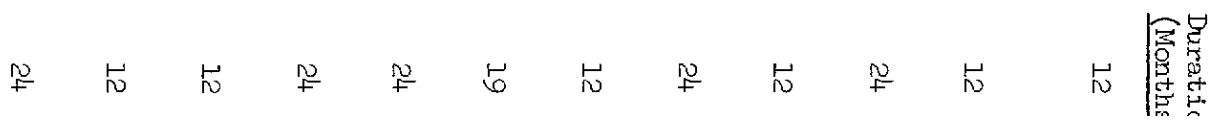




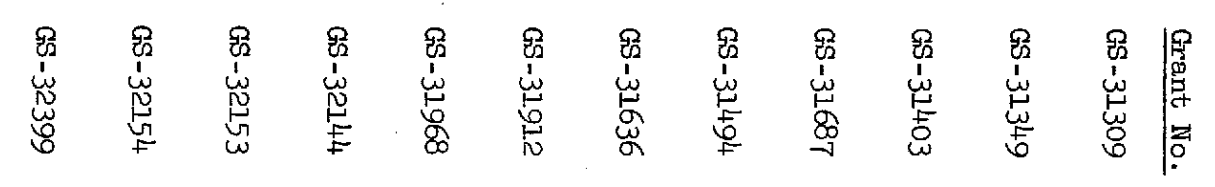

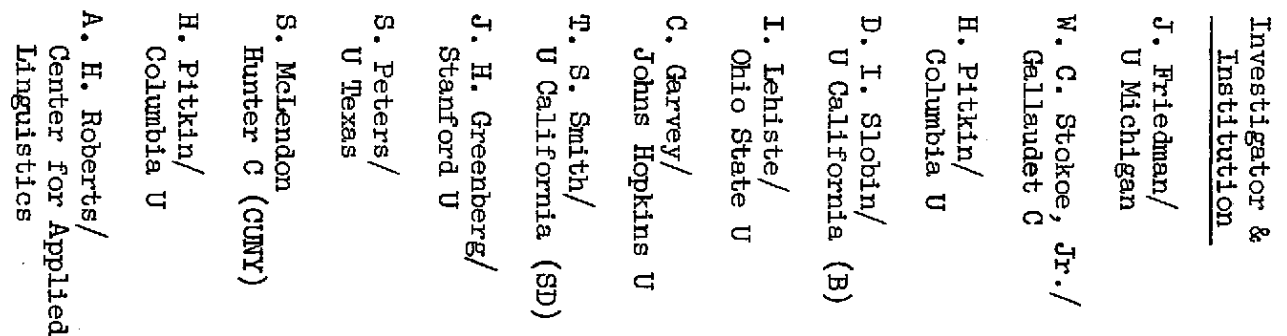

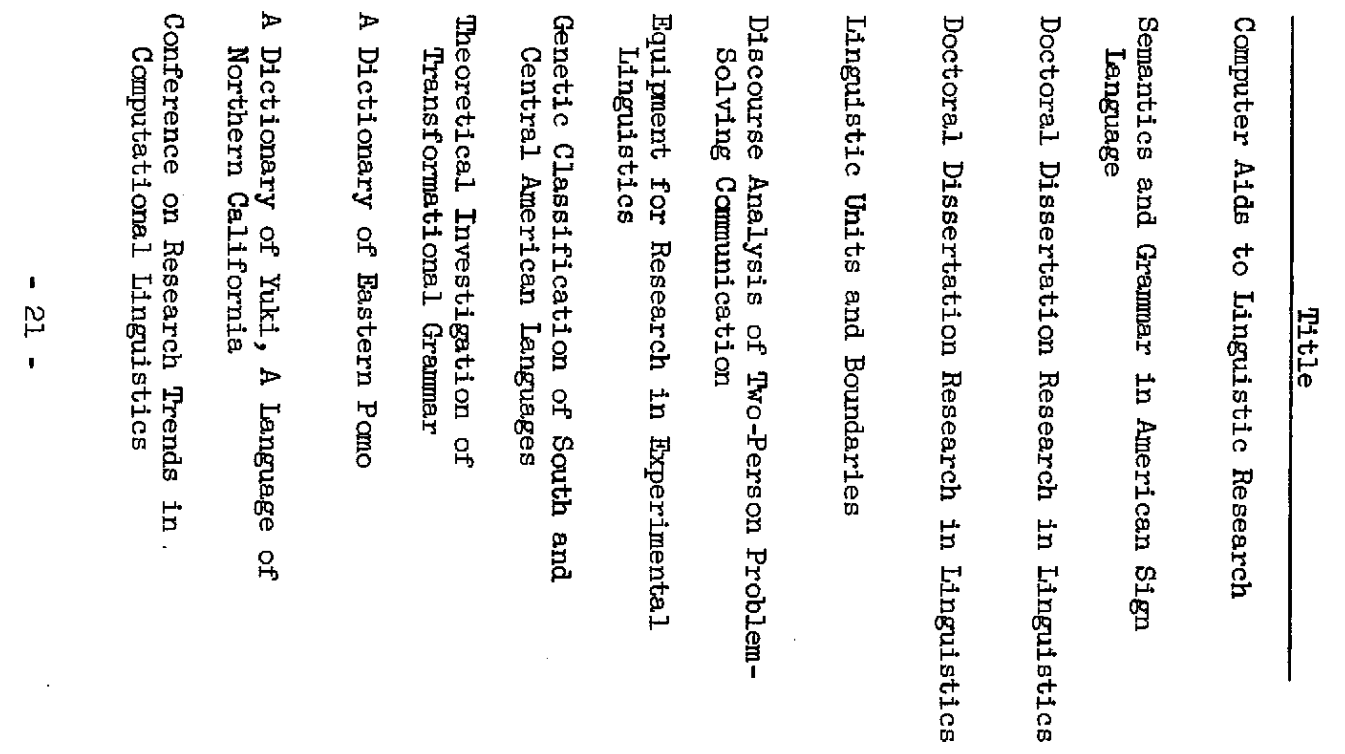

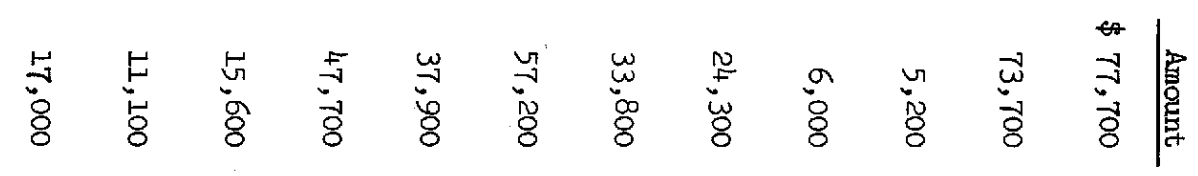

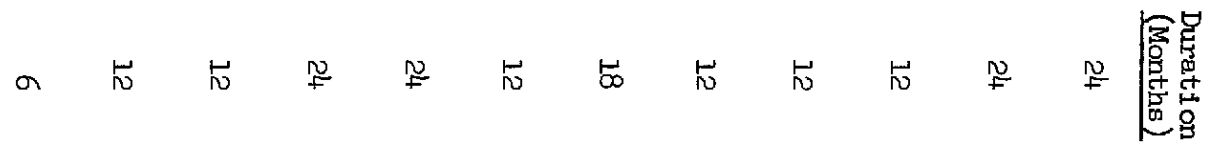




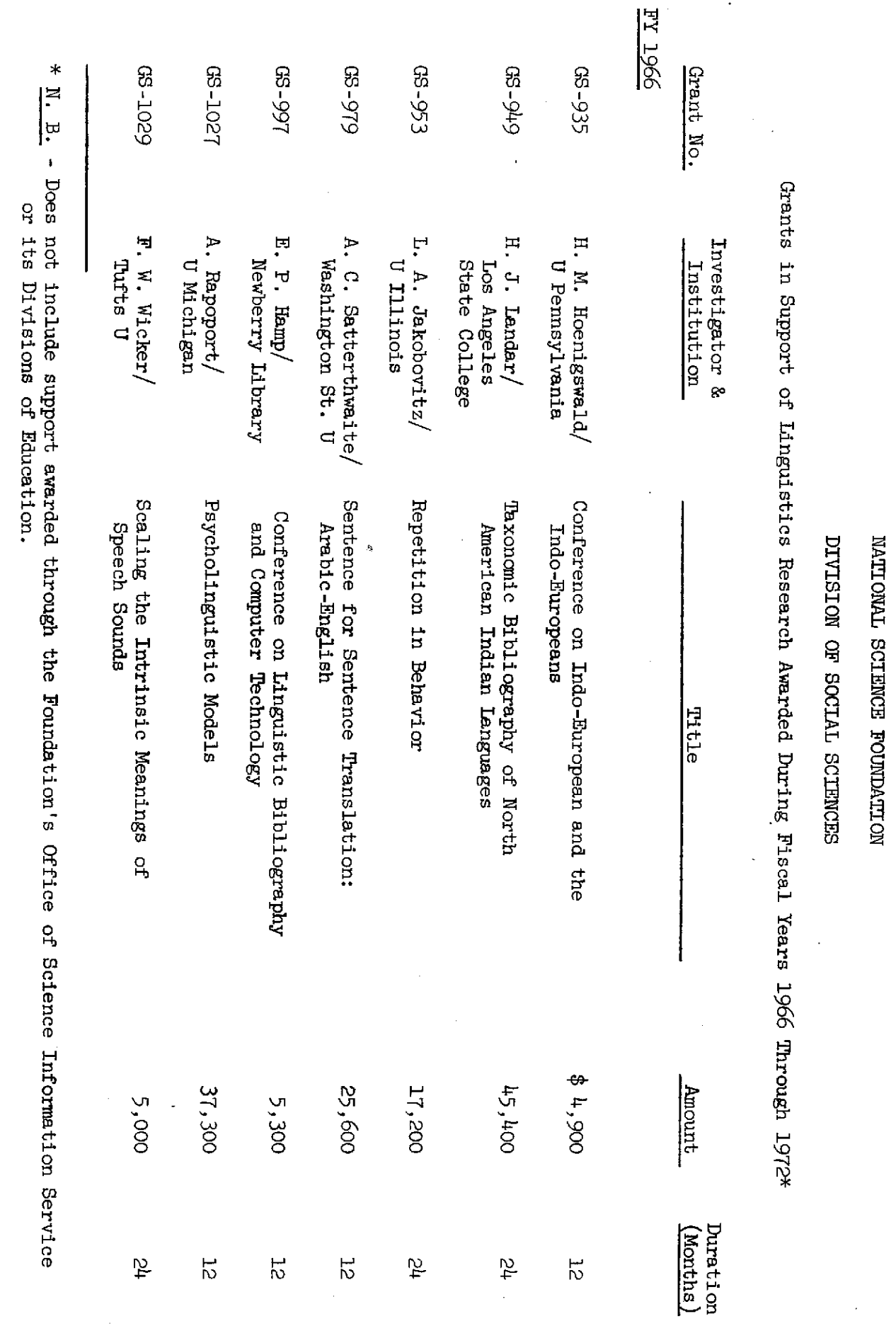




\section{ACLS grantees mentioned in an LSA Bulletin between 1970 and 1989}

NOTE: The names, affiliations, and proposals are listed below as they appear in the Bulletin. I omit travel grants.

Bulletin 43, April 1970, p. 30:

Received ACLS grants or fellowships for linguistics research: Erwin Esper, William O. Hendricks, Alfred Hudson, Kostas Kazazis, Anthony Salys.

Bulletin 57, June 1973, p. 25:

Three LSA members received fellowships for linguistic studies: Arthur Abramson, Sydney Lamb, Albert Schutz.

Bulletin 62, October 1974, p. 25:

The American Council of Learned Societies recently awarded 101 grants in aid for postdoctoral research in the humanities and related social sciences. Among the recipients were Ray Cordell Dougherty, Associate Professor of Linguistics, New York University: Pierce and Lovejoy on the History of Linguistic Methodology; Charles O. Frake, Professor of Anthropology, Stanford University: Language and Ethnic Identity; Andreas Koutsoudas, Professor of Linguistics, Indiana University: The Applications and Ordering of Grammatical Rules: Counter-feeding Order; La Raw Maran, Assistant Professor of Linguistics, Indiana University: A Linguistic Study of Jinghpaw-Kachin; Raoul S. Smith, Associate Professor of Linguistics, Northwestern University: Late I8th and Early 19th Century Manuscripts Written in Phonetic Transcription by Jonathan Fisher; Edward F. Tuttle, Assistant Professor of Italian, University of California, Los Angeles: Consonantal Weakening in Italo-Romance.

Bulletin 65, June 1975, pp. 13-14:

ACLS FELLOWSHIPS Ninety-four post-doctoral fellowships were awarded by the American Council of Learned Societies to scholars for periods of six months to one year. The following list includes the title of the research and university affiliation of individuals who received fellowships in linguistics and related areas. Connie C. Eble, Asst Prof English, U North Carolina: Late Old English Inflectional System. John M. Fyler, Asst Prof English, Tufts U: Ovidian Structure in Chaucer's Poetry. Richard E. Grandy, Assoc Prof Philosophy, U North Carolina: Study in Syntactic and Semantic Theories in Linguistics. Robert A. Macdonald, Prof Spanish, U Richmond: Linguistic Analysis of the Especulo of 
Alfonso X of Castile. Wilhelm F. H. Nicolaisen, Prof English, SUNY, Binghamton: A Concise Dictionary of Scottish Place Names. James T. Siegel, Assoc Prof Anthropology, Cornell U: Narrative and Language in a Traditional Society (Atjeh). Leslie L. Threatte, Jr., Asst Prof Classics, U Cal, Berkeley: The Grammar of Attic Inscriptions. Elizabeth C. Traugott, Assoc Prof Linguistics, Stanford U: The Space of Linguistic Time. Ardath M. Clark received an ACLS grant-in- aid for research in philology and diachronic linguistics with particular references to Middle English phonology, syntax, metrics, lexicology and dialectology. The title of the project is: 'Troilus and Criseyde: Editing a Critical Authoritative Text'.

Bulletin 66, October 1975, pp. 17-18:

ACLS FELLOWSHIPS, STUDY FELLOWSHIPS AND GRANTS-IN-AID During 1974-75, the American Council of Learned Societies, in national competitions, awarded 78 fellowships, 13 study fellowships and 133 grants-in-aid for post-doctoral research in the humanities and related social sciences. The following list includes the title of the research and university affiliation of individuals who received these awards in linguistics and related areas: Fellowships Elizabeth Traugott (Stanford Univ) The Space of Linguistic Time Craig B. Williamson (Swathmore Coll) Anthropological Approaches to Old English Poetry. Study Fellowships Glendon E. Bryce (Princeton Theological Seminary) Study in Theory and Application of Structuralist Methodologies Richard E. Grandy (Univ North Carolina) Study in Syntactic and Semantic Theories in Linguistics.

Grants-in-aid Edith A. Folb (Univ Cal, Irvine) Language and the Black Woman Eugene Green (Boston Univ) Linguistic and Social Properties of Massachusetts Place-names. Karl $\mathrm{H}$. Menges (Columbia Univ) The Grammar of the Tungus Languages.

Bulletin 69, June 1976, pp. 9-10:

ACLS GRANTS \& FELLOWSHIPS The American Council of Learned Societies (ACLS) awarded a large number of grants under its various programs during fiscal year 1975. Of these, 13 were in support of study and research in linguistics and related fields. The recipients were: Apostolos N. Athanassakis, University of California, Santa Barbara: A philological commentary on Iliad l; Weldon South Coblin, Jr., University of lowa: Chinese phonology of the Eastern Han period; Jarmila Emmerova, Charles University, Prague: Research at Emory University on contemporary American language and culture; Edith A. Folb, University of California, Irvine: Language and the black woman; Eugene Green, Boston University: Linguistic and social properties of Massachusetts place-names; Eleanor H. Jorden, Cornell: A sociolinguistic study in Japan of attitudes toward language 
and their effect on inter-cultural communication; Young Key Kim-Renaud, University of Hawaii: Research on vowel harmony in the Korean language; Bogusław Lawendowski, University of Warsaw: Research at Indiana University on a linguistic analysis of emotive forms of communication in American English; Karl H. Menges, Columbia University: The grammar of Tungus languages; Harold F. Schiffman, University of Washington: Incipient bilingualism among Sri Lanka's Indian Moors; Dan I. Slobin, University of California, Berkeley, and Dogan Cuceloglu, Hacettepe University: Research in the US and Turkey on language reform, person perception, and values in Turkey; D. Rodney Watson, University of Manchester: Research at SUNY Buffalo on minority group study with special reference to language use in interpersonal relations; George M. Williams, Jr., SUNY Buffalo: East German theories of the relation between the social use of language and linguistic structure.

In addition, ACLS has awarded ninety-seven fellowships for periods of 6 months to one year. The fellows are associated with 64 colleges and universities in the United States and Canada. The following list includes the title of the research and university affiliation of individuals who received fellowships in linguistics and related areas: Roger S. Bagnali, Columbia University: Study of Demotic Egyptian language and documents; Robert A. Frei din, Purdue University: Constraints on transformational grammar; Carol Kates, Ithaca College: A phenomenological description of linguistic meaning; Anson Rainey, Tel-Aviv University: A grammar of the West Semitized el-Amarna Tablets.

Bulletin 70, October 1976, p. 15:

ACLS GRANTS AND FELLOWSHIPS The American Council of Learned Societies recently announced that during 1975-76 several grants and fellowships were awarded to individual scholars for research in linguistics and related areas. The list of recipients, grouped according to the ACLS grant and/or fellowship program making the award, includes the academic affiliation and research project of the awardee. Grants for Research on Chinese Civilization: Jerry Norman, University of Washington: A comparative historical study of the Min Dialects; Lien-sheng Yang, Harvard University: A study of colloquial and semi-colloquial Chinese in T'ang, Sung, and Yrrian times. Research Fellowships for Recent Recipients of the PhD: Judith L. Aissen, Harvard University: The syntax of causative constructions; William J. Ashby, University of California, Santa Barbara: A sociolinguistic study of Parisian French; Christian J.W. Kloesel, Texas Tech University: Speculative grammar from Duns Scotus to Charles Peirce; Joan M. Maling, Brandeis University: Studies in diachronic and comparative syntax; Masayoshi Shibatani, University of Southern California: Interactions between syntax and 
logic. Grants-in-Aid: Stephen R. Anderson, University of California, Los Angeles: Syntax and morphology in the Nootka language; Morton W. Bloomfield, Harvard University: Oral poetry of the Xhosa and Zulu peoples of South Africa; Ronald E. Buckalew, Pennsylvania State University: An edition of AElfric's Grammar and Glossary; James M. Crawford, University of Georgia: Mobilian trade language; Richard C. Steiner, Yeshiva University: Glottalized ejectives in proto-Semi tic. Grants for Research in East European Studies: Antonin Dostál, Brown University: The beginning of Christianity among the Slavs: A textual investigation of the Euchologium Sinaiticum. Grants for Study of East European Languages: Albanian: Victor A. Friedman, University of North Carolina. Czech: Nancy B. Fowler, University of Michigan; Olga Peters, Yale University. Hungarian: Elizabeth M. La Cava, Indiana University. Macedonian: Alexander L. Albin, University of California, Los Angeles. Romanian: Thomas D. Cravens, University of Arizona; Ella Fry, University of Florida. Serbo-Croatian: Naomi Berkowitz, University of Washington. Slovenian: William R. Schmalstieg, Pennsylvania State University.

Bulletin 74, October 1977, p. 17:

ACLS GRANTS AND FELLOWSHIPS The American Council of Learned Societies (ACLS) recently announced the recipients of awards under the East European Study, Grants- inAid, Grants for Research on Chinese Civilization and Grants-in-Aid for Recent Recipients of the PhD programs. The following list includes the title of the research project and the university affiliation of the individuals who received grants in linguistics and related areas: Janet Byron (Cleveland SU) The Use of Two Standard Dialects among the Albanians of Yugoslavia; Andrew R. Durkin (Indiana U) The Life and Works of Sergej Aksakov; Margaret Egan (Wesleyan U \& Yale U) The Old Provencal vidas in the Medieval Commentary Tradition; Irene R. Fairley (Northeastern U) Visual Stylistics; Natalie K. Moyle (U Virginia) Turkish Dime Novels, The Transition from Folklore to Literature; Peter Steiner (U Michigan) A Comparative Study of Russian Formalism and Prague Structuralism; Shou-hsin Teng (U Massachusetts) Syntactic Structures of Amoy; Charles D. Van Tiiyl (Bacone C) Tibetan Language Materials; Stephen Wallace (U Houston) Jakartan Patterns of I and Thou; Joseph M. Williams (U Chicago) Linguistic Evidence of Social Mobility in Early Modern English.

In addition, the ACLS has awarded fellowships under the Recent Recipients of the PhD and Post-Doctoral Research Programs for research and study in the humanities and related social sciences. Those receiving fellowships in support of study and research in linguistics and related fields include: Ann Banfield (UC-Berkeley) Study of the Philosophy 
of Language; Elisabeth O. Selkirk (U Massachusetts) The Syllable in Phonological Representation; Robert M. Vago (Queens C-CUNY) The Description of Vowel Harmony.

Bulletin 97, October 1982, p. 17:

The American Council of Learned Societies has awarded Grants-In-Aid to 97 scholars including: Thomas T. Field, U MD, Baltimore and Arthur K. Spears, U CA, Santa Cruz. The American Council of Learned Societies announced that 75 post-doctoral fellowships had been awarded in a recent competition. Awardees included: Stephen Anderson, UCLA and Jane Grimshaw, Brandeis U.

Bulletin 101, October 1983, p. 13:

Donka F. Farkas of Pennsylvania S U was awarded a postdoctoral research grant in the 1983 ACLS East European Studies Grant Program.

Bulletin 105, October 1984, p. 16:

The American Council of Learned Societies has recently awarded 35 fellowships to recent recipients of the $\mathrm{PhD}$ for research in the humanities and social sciences including one grant to DANIEL E. EVERETT (S U Campinas, Brazil) to study "Comparative Syntax and Government Binding Theory." CLAUDIA ROSS (Purdue $U$ ) has been awarded a grant from the American Council of Learned Societies program in Chinese studies for a research project entitled "The Verb Phrase in Mandarin Chinese."

Bulletin 109, October 1985, p. 19:

The American Council of Learned Societies has awarded fellowships and grants to scholars under seven programs of support for research in the humanities and related social sciences. Linguists who have received these awards include: William $\mathrm{H}$. Baxter, $\mathrm{U}$ MI: A handbook of old Chinese phonology; W. South Coblin, U IA: A study of the old Tibetan inscriptions; David A. Frick, U CA-Berkeley: Polish sacred philology in the Reformation and Counter- Reformation; Victor A. Friedman, U NC-Chapel Hill: A comparative grammar of Balkan verbal categories; Paul W. Kroll, U CO: Revelations in verse and songs of transcendence in medieval Taoism; Theodore Huters, U MN: The influence of Qing dynasty theories of writing on the development of modern Chinese literature; Matthew W. Stolper, U Chicago: Xenophon's Belesys, the Kasr Archive, and Archaemenid Babylonia. 
Bulletin 113, October 1986, p. 16:

American Council of Learned Societies and the Social Science Research Council: Susan Gal, Rutgers U, has been awarded a research grant to work on a comparative study of bilingualism in East Europe.

Bulletin 117, October 1987, p. 19:

American Council of Learned Societies: The following were among 94 scholars who received grants-in-aid for postdoctoral research: Guy Bailey (TX A\&M): "The Roots of Black English; " and John Goldsmith (U Chicago): "A Generation of Linguists." The grants were funded by the John D. and Catherine T. MacArthur Foundation. Jaklin Kornfilt (Syracuse $U$ ) received a fellowship funded by the Carnegie Corporation and NEH to do research on Turkish syntax and syntactic theory.

Bulletin 121, October 1988, p. 19:

American Council of Learned Societies: The following received awards to pursue research: Janet Bing (Old Dominion U), sound system of Gborbo; Sara Kimbal, Hittite phonology; David W. Lightfoot (U MD-College Park), syntactic change; Hy V. Luong (Johns Hopkins $U$ ), language, political ideology, and history in modern Vietnam: 18671987; and Carol Scotton (U SC), lexical code borrowing and code switching in Kenya and Zimbabwe.

Bulletin 125, October 1989, p. 16:

American Council of Learned Societies: Frances Karttunen (U TX-Austin) was one of 87 recipients of grants-in-aid for post- doctoral research in the humanities and related social sciences. following people recently received fellowships for the academic year 1989-90: Dennis E. Baron (U IL-Urbana); Charles L. Briggs (Vassar C); Ellen I. Broselow (SUNY Stony Brook); Mary S. Erbaugh; Robert D. Hoberman (SUNY-Stony Brook); and Ronald K. Macaulay (Pitzer C) . Linguists who received summer stipends include: Lawrence K. Carpenter (U N FL); Paul D Deane (U Cntrl FL); Daniel L. Everett (U Pittsburgh); Edward L. Greenstein (Jewish Theological Sem of America); Janine Scancarelli (U KY); and Margaret J. Speas (U WI-Madison). Division of Research Programs grants were awarded to: Lloyd A. Kasten (U WI-Madison); Charles N. Li (U CASanta Barbara); Albert L. Lloyd (U PA); Leonard D. Newmark (U CA-San Diego); David S. Rood (U CO-Boulder); and Ladislav Zgusta (U IL- Urbana). Other grants were awarded to Allan R. Taylor (U CO-Boulder) to support a conference on the Greenberg classification of the native languages of the Americas and related problems in prehistory 
research and to Gene Searchinger to produce four one-hour films on the nature of language and the discipline of linguistics. 
National Endowment for the Humanities Grants in Linguistics: 1970, 1980, and 1989

1970 (11 awards)

Demetrius J. Georgacas, University of North Dakota, 'Modern Greek-English Dictionary'

Richard A. Demers, University of Arizona, 'Generative Phonology and Sound Change'

Nathan Susskind, CUNY Research Foundation, 'Great Dictionary of the Yiddish Language'

James L. Funkhauser, St. Louis Community College at Forest Park, 'Translating Negro

Dialect into Standard Dialect'

Fred W. Hanes, Indiana State University, Terre Haute, 'Cordell Gift of Rare Books'

Stanley M. Tsuzaki, University of Hawaii, Honolulu, 'Survey of Pidgin and Creole Languages: Bibliography'

R. L. Cowser, Jr, Wharton County Junior College, (title not available)

Michael J. Capek, MIT, 'A Comparative Syntax of Verbs in Shakespeare and Modern English'

Karen Brockman, Miami University, Oxford, 'American Indian Languages, Especially

Mesquakie and Algonkian'

Marron C. Fort, Villanova University, (title not available)

Russell A. Fraser, University of Michigan, 'Early Modern English Dictionary'

1980 (30 awards)

Jeffrey Heath, University of Michigan, 'Linguistic Theory And The Writing of Grammars'

Thomas A. Sebeok, Indiana University, 'The Effects of Nonverbal Cuing In Face-to-Face Interaction'

Michael Shapiro, Brown University, 'Language as Semiotic'

Franklin C. Southworth, Society for South India Studies, 'Linguistic Archaeology of The South Asian Subcontinent'

Thomas A. Wasow, Stanford University, 'Thematic Relations and Exceptions in the Theory of Grammar'

Saralyn R. Daly, Unaffiliated Independent Scholar, 'Description of Middle English Dialects'

Marion L. Huffines, Bucknell University, 'Investigation of the English of the Pennsylvania Germans'

Dennis L. Jarrett, Northern New Mexico Community College, 'A Linguistic Analysis of the Reading of a Literary Text' 
Tena L. Jeremiah, Unknown institution, 'An Ethnographic Study of the Communication of Urban Adolescent Black Women'

Muriel R. Schulz, Unknown institution, 'The Importance of Reading for Writers'

Raven I. McDavid, University of Chicago, 'American Dialects: Regional and Social'

Brian D. Joseph, Ohio State University, The Loss of the Infinitive in the Balkan Languages

Deborah F. Tannen, Georgetown University, 'A Comparison of Spoken and Written Narratives in English and Greek'

Edith A. Folb, San Francisco State University Foundation Inc., 'An Historical and Textual Analysis of Black Teenage Vocabulary Use'

Julia P. Stanley, Unknown institution, 'Identification of Syntactic Target Structures'

Arlene C. Malinowski, Unknown institution, 'Selected Linguistic Features of Contemporary Judeo-Spanish in Turkey'

Nancy C. Dorian, Unknown institution, 'Oral History of the East Sutherland (Scotland) Fisherfolk'

Marcia L. Hurlow, Unknown institution, 'Linguistics and the Remedial Writer' Ann W. Lewin, National Children's Museum, 'Planning for Communications Exhibit' Marianne Shapiro, Unknown institution, 'Translation of Three Old Provencal Grammars' Zygmunt Frajzyngier, University of Colorado, 'Structure of the Simple Sentence in ProtoChadic'

T. Givon, Southern Ute Indian Tribe, 'Ute Traditional Narrative and Word-order Change' John V. Van Cleve, Gallaudet University, 'Planning and Assessment Study of Encyclopedia of the Deaf and Deafness'

Marianne Mithun, SUNY Research Foundation, 'Cayuga Indian Grammar'

Peter M. Boyd-Bowman, SUNY Research Foundation, 'The Lexico Hispanoamericano del siglo XIX: Linguistic Analysis of Spanish American Documents'

Herbert A. Strauss, Research Foundation for Jewish Immigration, 'International Biographical Dictionary of Central European Emigres, 1933-45'

Jay L. Robinson, University of Michigan, 'Middle English Dictionary'

Lee A. Pederson, Emory University, 'Linguistic Atlas of the Gulf States' Michael Silverstein, University of Chicago, 'Lexicography in New World Context' Garland D. Bills, University of New Mexico, 'Symposium on Athapaskan Comparative Linguistics and Language Planning'

1989 (23 awards)

Benjamin H. Orr, Secondary School, 'Native Americans Language and Literature' Ronald K. Macaulay, Pitzer College, 'A Linguistic Study of Urban Scottish Dialects' 
Ellen Broselow, SUNY Research Foundation, 'The Sound Structure of the Major Arabic Dialects'

Charles L. Briggs, Vassar College, 'Gender and Power in Native South American Discourse'

Mary S. Erbaugh, Unaffiliated Independent Scholar, 'Language and Social Change in Modern China'

Fernando Penalosa, Unaffiliated Independent Scholar, 'Comparative Study of Mayan Folk Tales'

Ronald P. Schaefer, Southern Illinois University, 'English Translation of Emai Narratives'

Aaron Bar-Adon, University of Texas, 'The Saga of the Revival of Hebrew: The Second Phase (1904-18)'

Lawrence K. Carpenter, University of North Florida, 'Creation Cycle Myths in Lowland Ecuadorian Quichua: Form, Content, and Change'

Margaret Speas, University of Wisconsin, 'Phrase Structure and Transformational Theory: A Study in Linguistics'

Daniel L. Everett, University of Pittsburgh, 'Sound Systems of the Amazonian Languages'

Anne C. Lobeck, University of Alabama, Birmingham, 'Concepts of Proper Government in Linguistic Theory'

Paul D. Deane, University of Central Florida, 'Cognitive Explanations for Syntactic Constraints'

Charles K. Williams, University of Montana, 'The Comparative Method in Historical Syntax: The Chaldic Language Family of West Africa as a Case Study'

Janine Scancarelli, University of Kentucky, 'Cherokee Texts: Recording, Transcribing, and Analyzing to Produce a Linguistics Data Base'

Charles N. Li, University of California, Santa Barbara, 'A Functional Reference Grammar of Hmong--Phase II'

Ladislav Zgusta, University of Illinois, 'The MANUAL OF LEXICOGRAPHY: A New Version' Leonard Newmark University of California, San Diego, 'Albanian-English Dictionary' David S. Rood, University of Colorado, Boulder, 'Comparative Siouan Dictionary' Lee A. Pederson, Emory University, 'Completion of the Linguistic Atlas of the Gulf States' J. Kathryn Josserand, Unaffiliated Independent Scholar, 'A Handbook of Classic Maya Inscriptions (Western Lowlands)'

Gerard Diffloth, Cornell University, 'A Khmer (Cambodian) Etymological Lexicon' Allan R. Taylor, University of Colorado, 'Language and Prehistory in the Americas: A Conference on the Greenberg Classification' 
Fulbright-Hays (and other Fulbright) grants mentioned in an LSA Bulletin between 1970 and 1989

Bulletin 70, October 1976, p. 15:

1976-77 FULBRIGHT-HAYS AWARDS The following members of the Society have been selected American Fulbright- Hays Scholars for 1976-77 in linguistics and English as a foreign language: Michele Anciaux, University of Washington; Gerald Berent, University of North Carolina; James T. Critz, University of Washington; Ray C. Dougherty, New York University; James W. Gair, Cornell University; Beverly Hartford, Indiana University; Einar I. Haugen, Harvard University; Vera M. Henzl, Stanford University; John V. Hinds, University of Hawaii; Henry M. Hoenigswald, University of Pennsylvania; Gloria Jameson, California Polytechnic State University; D. Terrence Langendoen, City University of New York; Carlos Maeztu, University of San Carlos, Guatemala; Howard P. McKaughan, University of Hawaii; Blair Rudes, State University of New York, Buffalo; Susan A. Savage, Georgetown University; Margaret G. Sheil, State University of New York, Oneonta; Patricia Stanley, Washington State University; James Tollefson, Stanford University; Anthony J. Vitale, Cornell University.

Bulletin 74, October 1977 pp. 17-18:

1977-78 FULBRIGHT-HAYS AWARDS The Board of Foreign Scholarships has announced 482 awards to American scholars for work in 81 countries in a variety of disciplines for the program year 1977-78, and affiliation arrangements on U.S. campuses have been made for a comparable number of scholars from abroad. Those receiving awards in Linguistics and TEFL include: Liga Abolins, Indiana U; Adrian Akmajian, U Arizona; Judith E. Boss, Nebraska U; Teddi G. Bynum, Pählavi U; Nancy J. Cochrane, U Texas; David N. Cohen, USC; Gilbert D. Couts, American U; James T. Critz, U Washington; Kathleen L. Dahir, Georgia Southern C; James E. Devlin, SUNY-Oneonta; Nadine Dutcher, World Bank; James L. Fidelholtz, U Maryland; Catherine A. Fisher, U Illinois-Chicago Circle; William R. Gaines, Indiana U; George Galamba, San Francisco State C; Philip C. Hauptman, U Ottawa; Frederick G. Hensey, U Texas; Margaret Hunter, Millard School District, Delta, Utah; Richard S. Kayne, U Paris VIII; Edna L. Koenig, U Texas; Carl E. Lindeman, U Riyadh; Carlos A. Maeztu, U San Carlos; Derry L. Malsch, U Oregon; James I. McClintock, Michigan SU; Richard L. McLain, SUNY-Binghamton; Michael P. Menager, Albany Unified School District, California; Deborah J. Mickens, Seattle, WA; Carl R. Mills, U Cincinnati; James R. Nattinger, Portland State U; Emily R. Nutku, U Maryland; Theodore Olsson, U Pacific; Richard M. Payne, U Tunis; Elizabeth Riddle, U Illinois- Urbana; Mary K. 
Rippberger, North Valley, CA; Blair Rudes, SUNY-Buffalo; James D. Rumford, Department of Education, State of Hawaii; Philip A.S. Sedlak, USC; Margaret G. Shell, SUNY-Oneonta; Patricia Stanley, Washington SU; Richard Wanderer, Flushing, NY; Sandra Wenner, USC; Richard Wiest, American Library, Bucharest, Romania; Dick L. Williams, Lewis \& Clark C; Leslie N. Wilson, Florida SU; Arnold M. Zwicky, Ohio State U.

Bulletin 78, October 1978 pp. 16-17

1978-79 FULBRIGHT-HAYS AWARDS The Board of Foreign Scholarships and the U.S. International Communication Agency have announced 500 awards to American scholars for university teaching, advanced research or consultation in 90 countries for the program year 1978-79. Those receiving awards in linguistics and TEFL include: LIGA ABOLINS, Indiana U; DIANA E. BARTLEY, U Wisconsin, Milwaukee; M. LIONEL BENDER, Southern Illinois U; ELEANOR C. BOONE, Peace Corps Project, School for International Training, Brattleboro, VT; STEVEN W. BOSWELL, Washington DC; ARTHUR J. BRONSTEIN, CUNY Herbert H. Lehman C; E. WAYLES BROWNE, Cornell U; TEDDI G. BYNUM, Pahlavi U; CATHLEEN D. CAKE, U Pittsburgh; MARY B. CLEMENS, McKinley Community School for Adults; KATHLEEN L. DAHIR, Georgia Southern C; JOEL S. DIAMOND, McKinley High School Annex; NAN ELSASSER, U New Mexico; ROBERT H. ERICKSON, U Illinois; JAMES L. FIDELHOLTZ, U Maryland; CATHERINE A. FISHER, U Illinois; ALAN GARFIN- KEL, Purdue U; MARILYN C. GLENN, SUNY Buffalo; FRANK R. HUGUS, U Mass Amherst; MARGARET O. HUNTER, Millard School District, Delta, UT; ROBERT B. KAPLAN, U Southern California; ALAN S. KAYE, California SU Fullerton; CARL KIRSCHNER, Rutgers U; EDNA L. KOENIG, U Texas Austin; D. ROBERT LADD, JR., Cornell U; MARY MARTIN LANE, Indiana U; ANATOLE LYOVIN, U Hawaii; CARLOS A. MAEZTU, U de San Carlos, Guatemala; DIANA M. MEYERS, Kuwait U; DEBORAH J. MICKENS, Ohio U; GINO P. MUZZATI, Inst National d'Electricite et Electronique, Algeria; HARRY M. NEFF, Damavand C, Iran; GEOFFREY B. NUNBERG, CUNY Brooklyn C; EMILY R. NUTKU, U Maryland; ELIZABETH M. RIDDLE, U Illinois; ANDREW D. ROGERS, Austin, TX; JAMES D. RUMFORD, Hawaii State Dept of Education; JILL SAGARIN, Arizona SU; MARIANNE R. SANTI LLO, SUNY Buffalo; JUNE SCHLEUTER, Lafayette C; PHILIP A.S. SEDLAK, U Southern California; LOUISA R. STARK, U Wisconsin; ROSE MARIE TOSCANO, U Rochester; RICHARD M. WEIST, SUNY Fredonia; RICHARD C. WIEST; JOHN M. WOOD, National Bureau of Standards

Bulletin 94, March 1982, p. 8:

Fulbright awards for 1981-82 have been made to the following scholars in the field of linguistics: Irene T. Brosnahan (III State U), Matthew Y, Chen (U Calif-San Diego), David 
Chisholm (U Arizona), William H. Cook (W Carolina U), Michael Detlefsen (U Minn), Michael Flynn (Hampshire C), Eugene A. Fong (U Houston), Eugene Green (Boston U), James E . lannucci (St. Joseph's U), John B. Jensen (Fla Inti U), Katherine J. Johnson (Oscar Rose Comm C), Linda N. Levine (Mt Kisco, NY), Anatole Lyovin (U Hawaii), Norman A . McQuown (U Chicago), Rodney F. Moag (U Mich), Kenneth E . Naylor (Ohio State U), Dinh-Hoa Nguyen (So III U), Dennis M. O'Toole (Educ Testing Serv), Sandra Pinkerton (U Minn), Joel Rotenberg (MIT), Ann Louise Sen (U Rochester), Royal J. Skousen (Brigham Young U), Riley B . Smith (Bloorasburg State C) , Anthony J. Vitale (SUNY), Erhard F.K. Voeltz (Honolulu, Hawaii), James C. Woodward (Gallaudet C), and Louis V. Zuck (U Mich).

Fulbright-Hayes awards for 1981-82 have been made to the following graduate students in the field of linguistics: Daisy Addy (U Wash), James Fife (Calif Sch Professional PsychSan Diego), Robert Hasenfratz (Okla State U), Theodore Johnson (U Wash), Laura Keller (at large, No Dakota), Timothy Parker (U Calif-Berkeley), and Randall Preshun (Stanford $U)$.

Bulletin 100, June 1983, p. 7

Fulbright awards for 1982-83 have been made to the following scholars in the field of linguistics: James L. Armagost (Kansas S U), Faith Beane (U Chicago), John G. Bordie (U TX, Austin), Robert T. Botne (Northwestern U), Gregory N. Carlson (Wayne S U), William H. Cook (W Carolina U), Mary E. Faraci (Florida Atlantic U), James E. lannucci (St. Joseph's C), Karen M. Jensen (Georgetown U), Katherine J. Johnson (Oscar Rose Junior C), Avis T. Jones (Resource Consultants, Inc.), Thomas Magner (PA S U), Roy C. Major (WA S U), Kevin M. McCarthy (U FL), Michael I. Miller (VA Commonwealth U), Carl R Mills (U Cincinnati), Jan L. Perkowski (U VA), Dennis R. Preston (SUNY at Fredonia), John R. Ross (Massachusetts Institute of Technology), Carol M. Scotton (Michigan S U), Stanislav Segert (UCLA), and Richard G. Werner (CO S U).

Bulletin 103, March 1984, p. 12

FULBRIGHT-HAYS AWARDS. The following is a list of graduate students of linguistics who have received Fulbright-Hays Awards for 1983-84, with their U.S. institutions and the countries in which they will study: Nina Ardery, IN U, Bloomington: W Germany; Victoria Bergvall, Harvard U: Kenya; Catherine Bodin, U NC, Chapel Hill: France; Kathie Carpenter, Stanford U: Thailand; George T. Childs, U CA, Berkeley: Liberia; Katherine Cooper, IN U, Bloomington: W Germany; Andrea Dunn, U IL, Urbana-Champaign: 
Tanzania; David Lund, St Olaf C: W Germany; Ruth Lunt, U Pittsburgh: W Germany; Catherine Neill, Georgetown U: Thailand; Joel Nevis, no institutional affiliation, $\mathrm{OH}$ : Finland; Michael L. O' Dell, IN U, Bloomington: Finland; Gregory Trauth, U IL, UrbanaChampaign: W Germany; John Whitman, Harvard U: S Korea. o

FULBRIGHT AWARDS. The following scholars in the field of linguistics have been awarded Fulbrights for 1983-84: Farrell Ackerman, U CA, Berkeley: Hungary; Andrew S. Allen, U TN, Knoxville: Romania; Faith Whitney Beane, U Chicago: Bulgaria; Simon Be las co, U SC: France; Joel Bradshaw, U Hawaii: Romania; William H. Cook, Western Carolina U: Poland; James E. Copeland, Rice U: W Germany; Mary E. Faraci, FL Atlantic U: Romania; Morris Halle, MIT: France; Randall J. Henrick, U NC, Chapel Hill: England \& France; Robert K. Herbert, SUNY, Binghamton: Poland; Taco J. Homburg, U MI: Netherlands; Katherine J. Johnson, Oscar Rose Jr C: Poland; Avis T. Jones, McLean, VA: Gabon; Johanna E. Katchen, PA S U: Yugoslavia; Robert S. Kirsner, UCLA: Netherlands; Anthony S. Kroch, U PA: Brazil; Pamela Martin, Teachers C, Columbia U: Yugoslavia; Kevin M. McCarthy, U FL: Saudi Arabia; Michael I. Miller, VA Commonwealth U: Poland; Dennis M. Muchisky, U NM: Poland; Mark S. Patkowski, Hofstra U: Rwanda; Jan L. Perkowski, U VA: Romania; Ernest A. Scatton, SUNY, Albany: Bulgaria; Jacquelyn E. Schachter, USC: Israel; Richard W. Schmidt, U HI: Brazil; Robert M. Vago, Queens C, CUNY: Israel.

\section{Bulletin 107, March 1985, p 13}

Fulbright-Hays Awards. The following is a list of graduate students of linguistics who have received Fulbright-Hays awards for 1984-85, with their US institutions and the countries in which they will study: David Bogdan (U FL), Poland; Julie Cionco (NM S U), West Germany; Robert M. DeSilva (U MI), Finland; Karen Gallob (U CO-Boulder), Mauritius; Amanda Hirsch (Oberlin C), Austria; Merelyn Mims (U Cincinnati), Cameroon; Lori A. Schwabenbauer (La Salle U), Fiji; Eva L. Szalay (VA Poly tech Inst \& S U), West Germany; John Whitman (Harvard U), South Korea; Jessica S. Williams (U PA), Singapore.

Fulbright Awards. The following linguists have been awarded Fulbrights for 1984-85: Farrell Ackerman (U CA-Berkeley), Hungary; Faith W. Beane (U Chicago), Bulgaria; Helen C. Beresovsky (U PA), Norway; George N. Clements (Cornell U), Kenya; William J. Greenberg (UCLA), Poland; Beverly S. Hartford (IN U), Nepal; Robert K. Herbert (SUNYBinghamton), Poland; Thomas N. Huckin (U MI), Brazil; Grover M. Hudson (MI S U), Ethiopia; John P. Hutchison (Boston U), Niger; M. Karen Jogan (Albright C), Peru; Theodore C. Johnson (Walla Walla C) , Poland; Avis T. Jones, Gabon; Frances E. Karttunen 
(U TX-Austin), Finland; Anthony S. Kroch (U PA), Brazil; Mehdi Marashi (U UT), USSR; Pamela Martin (Teachers C of Columbia U), Yugoslavia; John J. Ohala (U CA- Berkeley), Denmark; Sandra Pinkerton (U MN), Brazil; James A. Reeds (U MO-Kansas City), Poland; Roger B. Speegle (TX Wesleyan C) , West Bank; Erhard F. Voeltz, Burundi; Margaret K. Woodworth (U GA), Poland; Martha S. Wright (U MA-Amherst), Netherland

Bulletin 109, October 1985, p. 19

The following are this year's Fulbright scholars, with their home institutions and the countries where they are teaching or doing research: H.G. Bartelt, Yavapai C: West Germany; Katherine A. Demuth , U CA- Berkeley: Mozambique; Richard M. Frankel, Wayne SU: Sweden; William J. Frawley, U DE: Poland; Daryl K. Gibb, Automated Language Processing Systems (Provo, UT): Finland; Robert J. Jarvella, U Umea (Sweden): Poland; Theodore C. Johnson, U WA: Poland; John M. Lipski, U Houston: Philippines; Adam Makkai, U IL-Chicago: Singapore; Muriel R. Schulz, CSU-Fullerton: Austria; Susan C. Shepherd, Free U of Berlin: Poland; William A. Smalley, Bethel C (MN): Thailand; Erhard F.K. Voeltz, independent scholar, Minneapolis: Burundi.

Bulletin 111, March 1986, p. 14

Fulbright Awards: The following linguists have been awarded Fulbrights for 1985-86: H.G. Bartelt, Yavapai C: West Germany; Katherine A. Demuth, U CA-Berkeley: Mozambique; Richard M. Frankel, Wayne SU: Sweden; William J. Frawley, U DE: Poland; Daryl K. Gibb, Automated Language Processing Systems, Provo, UT: Finland; Robert J. Jarvella, U Umea (Sweden): Poland; Theodore C. Johnson, U WA: Poland; John M. Lipski, U Houston: Philippines; Adam Makkai, U IL-Chicago: Singapore; Muriel R. Schulz, CSUFullerton: Austria; Susan C. Shepherd, Free U-Berlin: Poland; William A. Smalley, Bethel C: Thailand; Erhard F.K, Voeltz, independent scholar, Minneapolis, MN: Burundi.

Fulbright-Hayes Awards: The following is a list of graduate students of linguistics who have received Fulbright-Hayes awards for 1985-86, with their US institutions and the countries in which they will study: Steven Diamond, U CA-Berkeley: Taiwan; Nicholas G. Faraclas, U CA- Berkeley: Papua New Guinea; Mark R. Hale, Harvard U: West Germany; Michael Inman, Colgate U: Sri Lanka; Marshall Lewis, no institutional affiliation, Indiana: Togo; Jay Nash, U IL-Urbana-Champaign: Zaire; Ann L. Sittig, U NE-Lincoln: Peru; John Te Velde, U WA: West Germany; Samuel Walters, U TX-Austin: Tunisia. 
Bulletin 115, March 1987, p. 12

Fulbright Awards: The following linguists have been awarded Fulbrights for 1986-87:

John Algeo, U GA: United Kingdom; A. L. Becker, U MI: Malaysia; Charles M. Carlton, U

Rochester: Brazil; J R. Cowan, U IL-Urbana: West Germany; Dorothy Disterheft, U SC:

Ireland; Hans H. Hock, U IL-Urbana: India; Judith N. Levi, Northwestern U: India; Joan M. Maling, Brandeis U: Ireland; David F. Marshall, U ND: China; William W. Megenney, U CARiverside: Venezuela; Rocky V. Miranda, U MN: India; Susan C. Shepherd, Free U Berlin: Poland. 


\section{National Institute of Mental Health grants in 1973}

\section{From LSA Bulletin 64, March 1975, p. 43}

NIMH RESEARCH GRANTS AWARDED The Division pf Extramural Research Programs of the National Institute of Mental Health (NIMH) awarded 1,329 research grants in fiscal 1973. Eighteen of these were for research in linguistics and related areas, for a total of $\$ 976,63$. The following list includes the investigator, institution, title, and amount for each such linguistic research grant : Christopher W. Alexander, U California, Berkeley. Environmental Pattern Language, $\$ 56,768$. James E. Deese, U Virginia. Psycholinguistic Investigations, $\$ 20,283$. Charles A. Ferguson, Stanford U. Processes of Cultural, Lexical Change, $\$ 4,228$. James J. Fox, Harvard U. Formal Systems of Dyadic Languages, \$28,863. Catherine J. Garvey, Johns Hopkins U. Varieties and Functions of Early Social Speech, $\$ 24,257$. Henry G. Gleitman, U Pennsylvania. The Acquisition of Linguistic Structure, $\$ 10,359$. John J. Gumperz, U California, Berkeley. Language-Behavior Research Laboratory, $\$ 80,494$ Morris Halle, Massachusetts Institute of Technology. The Study of Language, $\$ 274,626$. Zellig S. Harris, U Pennsylvania. Objective and Subjective Components of Grammar, $\$ 75,873$. James J. Jenkins, U Minnesota. Studies of Speech Perception and Recognition, $\$ 24,779$, Sally McLendon, Hunter C. Cultural Patterning of Information in Discourse, $\$ 33,913$. Claudia I. Mitchell-Kernan, Harvard U. The Acquisition of Sociolinguistic Skills by Children, $\$ 50,127$. Douglas L. Nelson, U South Florida. Words as Sets of Features Coding Phonological Cues, \$20,961. Charles E. Osgood, U Illinois. Studies on Comparative Psycholinguistics, \$81,332. David Premack, U California, Santa Barbara. Language and Infra-human Primates, $\$ 48,605$. Joel F. Sherzer, U Texas, Austin. Ethnographic Patterns of Speech, \$5, 295, Edward E. Smith, Stanford U. Visual and Semantic Processing of Letters and Words, $\$ 29,876$. Robert L. Williams, Institute of Black Studies. Conference on Language Development in the Black Child, $\$ 11,996$. 